Article

\title{
Adsorption of Anionic Dyes from Wastewater onto Magnetic Nanocomposite Powders Synthesized by Combustion Method
}

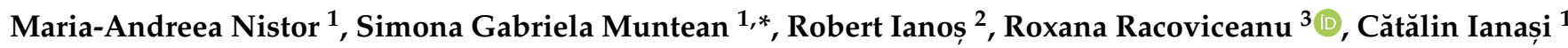 \\ and Liliana Cseh ${ }^{1, *}$ \\ 1 “Coriolan Drăgulescu" Institute of Chemistry, 24 Mihai Viteazu, 300223 Timisoara, Romania; \\ anistor@acad-icht.tm.edu.ro (M.-A.N.); cianasic@yahoo.com (C.I.) \\ 2 Faculty of Industrial Chemistry and Environmental Engineering, Politehnica University Timișoara, \\ 6 Pârvan Blv., 300223 Timisoara, Romania; robert_ianos@yahoo.com \\ 3 Faculty of Pharmacy, "Victor Babes" University of Medicine and Pharmacy Timișoara, \\ Eftimie Murgu Squareno.2, RO-300041 Timișoara, Romania; babuta.roxana@umft.ro \\ * Correspondence: sgmuntean@acad-icht.tm.edu.ro (S.G.M.); lilianacseh@gmail.com (L.C.)
}

check for updates

Citation: Nistor, M.-A.; Muntean, S.G.; Ianoș, R.; Racoviceanu, R.; Ianași, C.; Cseh, L. Adsorption of Anionic Dyes from Wastewater onto Magnetic Nanocomposite Powders Synthesized by Combustion Method. Appl. Sci. 2021, 11, 9236. https:// doi.org/10.3390/app11199236

Academic Editor: David García Fresnadillo

Received: 12 September 2021 Accepted: 29 September 2021 Published: 4 October 2021

Publisher's Note: MDPI stays neutral with regard to jurisdictional claims in published maps and institutional affiliations.

Copyright: (c) 2021 by the authors. Licensee MDPI, Basel, Switzerland. This article is an open access article distributed under the terms and conditions of the Creative Commons Attribution (CC BY) license (https:// creativecommons.org/licenses/by/ $4.0 /)$.

\begin{abstract}
In the present study, new magnetic nanocomposites were successfully prepared by combustion method, characterized by X-ray diffraction, Fourier transform infrared spectroscopy, magnetic measurements, $\mathrm{N}_{2}$ adsorption-desorption thermal analysis, and scanning electron microscopy, and tested as adsorbents for the removal of anionic dyes (Acid Yellow 42 and Acid Red 213) from aqueous solutions. The influence of process variables solution $\mathrm{pH}$, adsorbent dose, initial dye concentration and temperature on the adsorption was evaluated. The best kinetic model that fitted with experimental data was a pseudo-second order model, and the equilibrium data were correlated by Langmuir isotherm model for the investigated dyes. Maximum removal efficiencies of $98.54 \%$ and $97.58 \%$ was obtained for Acid Yellow 42 and Acid Red 213, respectively, indicating the superior adsorption capacity of the new synthesized magnetic nanocomposites. The thermodynamic parameters indicated the spontaneous and endothermic nature of the adsorption process.
\end{abstract}

Keywords: magnetic nanocomposites; combustion synthesis; dye; adsorption

\section{Introduction}

The intense industrialization of recent years has led to an increase in water pollution, making it one of the main environmental problems. Numerous industries, such as textiles, leather, paper, cosmetics, and food, are the main generators of huge amounts of water contaminated with dyes $[1,2]$. Their uncontrolled discharge into the aquatic environment, without prior treatment, has a strong negative impact on the ecosystem [3]. In addition to the unsightly appearance, the presence of dyes in the water reduces the penetration of light, which affects the photosynthetic activities of the aquatic flora; the amount of dissolved oxygen is also low, thus affecting the aquatic ecosystem [4,5].

The complex chemical structure of the dyes makes them resistant to biodegradation, light, heat and oxidizing agents, enabling their high persistence in the environment [6-9]. The presence of dyes in water has a negative impact not only on the environment, but also on human health, due to their toxic, mutagenic and carcinogenic properties [1,10-12]. These are a few of the factors that indicate the importance of treating these contaminated waters using the most effective methods.

In order to reduce the pollution of contaminated waters with dye content, several physical, chemical and biological methods of water treatment have been investigated, including adsorption [13-16], advanced oxidation [17], photocatalysis [18], filtration [19], catalytic degradation [20], coagulation/flocculation [21], reverse osmosis [22] and biodegradation [23]. The approaches have had different success rates. The chemical methods applied for dye removal from wastewater have some disadvantages, such as the high cost 
of large-scale application, the incomplete mineralization of the organic compound, and the production of toxic by-products $[13,24]$. In the case of biological methods, the disadvantages include the low efficiency in removing certain dyes with stable molecular structures, the appearance of sludge, and the production of harmful secondary compounds [13,25]. Among all the decontamination methods, physical adsorption proves to be unique in removing dyes from contaminated wastewater, because it consists of a simple operation process, has a high selectivity for contaminants, results in the low production of non-toxic by-products, and has low operating costs and high efficiency.

Various materials, such as activated carbon [26], zeolites [27], mesoporous silica [28], metal organic frameworks (MOF) [29], polymers [30], and by-products of agriculture [31], have been investigated as potential adsorbents for wastewater treatment. Among these materials, activated carbon (AC) has shown good adsorption performance for a wide range of pollutants, due to its porous structure and large specific surface area. However, powder-activated carbon has a major drawback: the difficulty of separating it from aqueous solutions. To overcome this problem, activated carbon-based magnetic composite powders have attracted much interest. In the recent years, magnetic nanocomposites have been proven to be highly efficient in removing dyes from wastewater because they are easy to control and can be very quickly separated from solution by applying an external magnetic field [32-35].

Different synthesis methods have been used for the preparation of magnetic nanocomposites, including sol-gel [36], solvothermal [37], hydrothermal [38], pyrolysis of organometallic compounds [39], co-precipitation [40], and the combustion method [41]. Most of these methods have disadvantages as they involve several steps in the synthesis process, the reaction is difficult to control, and they involve long reaction times and toxic raw materials. On the other hand, the combustion method used in this study has proven to be a versatile, simple and safe method. Combustion synthesis is a quick and easy process that requires simple equipment, thus it can save time and energy. At the same time, the combustion method allows the efficient synthesis of a variety of nanomaterials with high yields and high surface areas [42,43].

The aim of this study is the synthesis of a new material, which combines the adsorbent properties of activated carbon with the magnetic ones of iron oxides. This new material was further tested as an adsorbent for anionic dyes. The synthesized adsorbents were characterized in terms of structural, morphological and magnetic properties. In the adsorption studies, the effects of the experimental parameters solution $\mathrm{pH}$, adsorbent dose, temperature and initial dye concentration were evaluated. Kinetics, equilibrium and thermodynamic studies were carried out in order to describe the adsorption process.

\section{Materials and Methods}

\subsection{Materials}

Iron(III) nitrate nonahydrate $\mathrm{Fe}\left(\mathrm{NO}_{3}\right) \cdot 9 \mathrm{H}_{2} \mathrm{O}$ from Sigma Aldrich $(>98 \%)$, L-arginine $\mathrm{C}_{6} \mathrm{H}_{14} \mathrm{~N}_{4} \mathrm{O}_{2}$ from Merck $(>99 \%)$, and activated carbon with different specific surface areas (AC $\left(1000,1300,1700 \mathrm{~m}^{2} / \mathrm{g}\right)$ ) from Roth were used for the synthesis of magnetite/carbon nanocomposites.

\subsection{Synthesis of Magnetic Nanocomposites}

The synthesis of magnetic nanocomposites was performed by an improved combustion technique, as previously described [42,43]. In this case, iron nitrate was used as an oxidizing agent and L-arginine was used as a reducing agent or fuel (Equation (1)). The recipe was calculated in order to obtain $10 \mathrm{~g}$ of composite material (PM), in which the magnetite:carbon mass ratio was 1:4.

$$
102 \mathrm{Fe}\left(\mathrm{NO}_{3}\right)_{3}+46 \mathrm{C}_{6} \mathrm{H}_{14} \mathrm{~N}_{4} \mathrm{O}_{2}=34 \mathrm{Fe}_{3} \mathrm{O}_{4}+276 \mathrm{CO}_{2}+322 \mathrm{H}_{2} \mathrm{O}+245 \mathrm{~N}_{2}
$$

The influence of the specific surface area of activated carbon on the nanocomposite performance was investigated. Additionally, the effect of the thermal treatment time span 
on the PM properties was observed. The working conditions used in the synthesis of PM are presented in Table 1.

Table 1. Conditions for the synthesis of magnetic nanocomposites.

\begin{tabular}{cccccc}
\hline Sample & $\begin{array}{c}\mathbf{S}_{\text {BET }} \\
\text { Activated Carbon } \\
\left(\mathbf{m}^{\mathbf{2}} / \mathbf{g}\right)\end{array}$ & $\begin{array}{c}\text { Mass } \\
\text { Activated Carbon } \\
\mathbf{( g )}\end{array}$ & $\begin{array}{c}\text { Mass } \\
\mathbf{F e}\left(\mathbf{N O}_{\mathbf{3}} \mathbf{~}_{\mathbf{3}} \cdot \mathbf{9} \mathbf{H}_{\mathbf{2}} \mathbf{O}\right. \\
\mathbf{( g )}\end{array}$ & $\begin{array}{c}\text { Mass } \\
\mathbf{C}_{\mathbf{6}} \mathbf{H}_{\mathbf{1 4}} \mathbf{N}_{\mathbf{4}} \mathbf{O}_{\mathbf{2}} \\
\mathbf{( g )}\end{array}$ & $\begin{array}{c}\text { Thermal Treatment } \\
\text { Time Span } \\
(\mathbf{m i n})\end{array}$ \\
\hline PM 1 & 1000 & 8.00 & 10.47 & 2.04 & 90 \\
PM 2 & 1300 & 8.00 & 10.47 & 2.04 & 90 \\
PM 3 & 1700 & 8.00 & 10.47 & 2.04 & 90 \\
PM 4 & 1700 & 8.00 & 10.47 & 2.04 & 60 \\
\hline
\end{tabular}

Iron nitrate and L-arginine were mixed with different types of activated carbon (with specific surface areas ranging between 1000,1300 and $1700 \mathrm{~m}^{2} / \mathrm{g}$ ) in a round bottom flask, in the quantities specified in Table 1. The soluble raw materials were dissolved in $20 \mathrm{~mL}$ of distilled water. Afterwards, the flask was placed in a heating mantle preheated at $400{ }^{\circ} \mathrm{C}$ to ignite the combustion reaction, in the absence of air. In order to prevent air from getting inside the flask during the combustion reaction, the flask containing the reactant mixture was closed with a glass tap. The gases generated during the combustion reaction create positive pressure, so that air cannot enter the flask. During the combustion reaction, the tap was set to the open position to allow the combustion gases to exit the flask. At the end of the combustion process the tap was set to the closed position and the flask was removed from the heating mantle. The same experimental procedure was used for all samples. The sample was kept in the heating mantle for $90 \mathrm{~min}$ in the case of samples PM1-PM3 and 60 min in the case of sample PM4.

The obtained samples were washed with distilled water, dried at $80^{\circ} \mathrm{C}$, and ground. The final material was in all cases a black magnetic powder.

\subsection{Characterization Methods}

The phase composition of the powders was determined by X-ray diffraction (XRD), using a Rigaku Ultima IV instrument. X-ray diffraction patterns were recorded using $\mathrm{CuK} \alpha$ radiation.

The functional surface groups were evidenced using Fourier transform infrared (FT-IR) spectroscopy. Infrared spectra were recorded on the Shimadzu IR Prestige-21, using the potassium bromide pellet method, in the range of 400 to $4000 \mathrm{~cm}^{-1}$.

The behaviors in the external magnetic field of the obtained nanocomposites were studied in low-frequency $(50 \mathrm{~Hz}) \mathrm{AC}$ applied magnetic fields, using a laboratory-manufactured induction hysteresigraph installation equipped with a data acquisition system [44].

The porous structure characteristics of the investigated samples were determined from the nitrogen adsorption-desorption isotherms. The $\mathrm{N}_{2}$ adsorption-desorption isotherms were recorded at 77K using a QUANTACHROME Nova 1200e device. The samples were degassed at $110^{\circ} \mathrm{C}$ for $15 \mathrm{~h}$. The specific surface areas were determined using the Brunauer-Emmett-Teller (BET) method and the pore size distributions were derived with the Barrett-Joyner-Halenda (BJH) method from the desorption curves.

The thermal behavior of the samples was studied in the range $25-1000{ }^{\circ} \mathrm{C}$ by thermal analysis, using a Netzsch Sta 449C device. To record The TG and DSC curves, the sample was placed in a platinum crucible and heated in an atmosphere of air with a heating rate of $10^{\circ} \mathrm{C} / \mathrm{min}$.

Scanning electron microscopy (SEM) was used to investigate the morphology of the magnetic nanocomposites by using an Inspect-S scanning electron microscope.

\subsection{Adsorption Experiments}

Two anionic industrial dyes, Acid Yellow 42 (AY 42; $\mathrm{C}_{32} \mathrm{H}_{24} \mathrm{~N}_{8} \mathrm{Na}_{2} \mathrm{O}_{8} \mathrm{~S}_{2}$ ) and Acid Red 213 (AR 213; $\mathrm{C}_{16} \mathrm{H}_{13} \mathrm{~N}_{3} \mathrm{O}_{4} \mathrm{~S}$ ), obtained from Colorom Codlea, were used as adsorbates for 
the adsorption studies. Dye solutions at different concentrations were obtained by dilution with distilled water from a stock solution $(450 \mathrm{~g} / \mathrm{L})$. The $\mathrm{pH}$ value of the dye solutions was adjusted using $\mathrm{HCl}$ or $\mathrm{NaOH}$ solutions $(0.1 \mathrm{~mol} / \mathrm{L})$.

For the adsorption experiments, $20 \mathrm{mg}$ of the PM (adsorbent) was dispersed in $20 \mathrm{~mL}$ of dye solution. The adsorption process was carried out in Erlenmeyer glasses, using a thermostat shaker with a constant stirring speed of $200 \mathrm{rpm}$ for $240 \mathrm{~min}$ at $25^{\circ} \mathrm{C}$. After adsorption, the concentration of the dye solution was spectrophotometrically determined, and the absorbance at $\lambda_{\max }$ (the wavelength of the maximum value of absorbance) specific to each dye ( $409.0 \mathrm{~nm}$ for AY 42 and $544.5 \mathrm{~nm}$ for AR 213) was recorded. The adsorption capacity $\left(q_{t}\right)$ and percentage of dye removal $(R)$ were calculated using Equations (2) and (3), respectively.

$$
\begin{gathered}
q_{t}=\frac{\left(C_{0}-C_{t}\right) \cdot V}{W} \\
R=\frac{C_{0}-C_{e}}{C_{0}} \cdot 100
\end{gathered}
$$

where $C_{0}, C_{t}$, and $C_{e}$ are the concentrations of the dye solution at the initial time, at different periods of time, and at the equilibrium $(\mathrm{mg} / \mathrm{L})$, respectively; $V$ is the volume of solution (L), and $W$ is the mass of adsorbent (g).

\section{Results and Discussion}

\subsection{Structural Characterization of the Magnetic Nanocomposites}

\subsubsection{X-ray Diffraction (XRD)}

X-ray diffraction analysis was applied to determine the crystalline structure of the synthesized magnetic nanocomposites. Figure 1 illustrates the XRD pattern of the PM1, PM2, PM3 and PM4 samples compared to activated carbon.

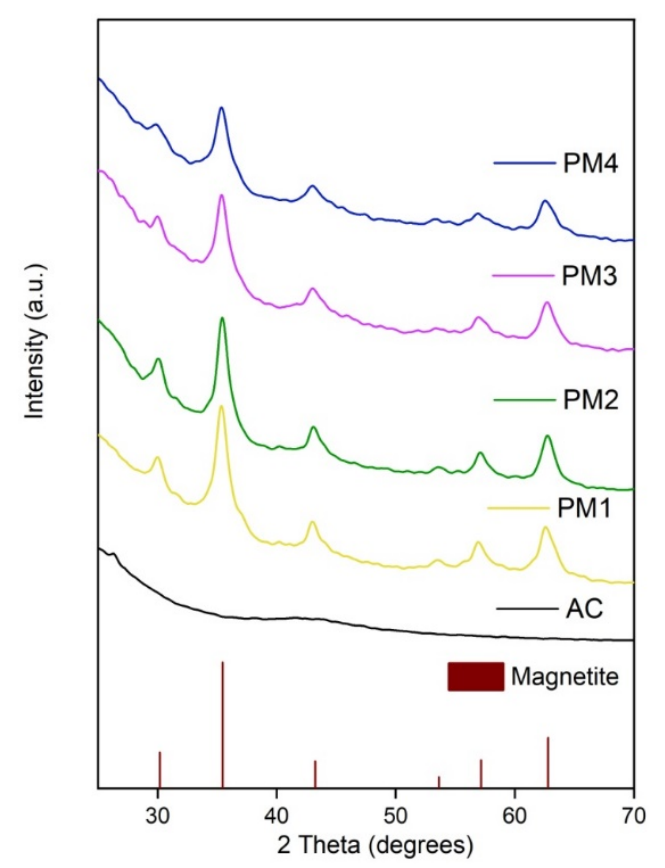

Figure 1. X-ray diffraction pattern of activated carbon and magnetic nanocomposites.

Figure 1 indicates that AC exhibits a very broad diffraction peak characteristic for an amorphous structure, which is in accordance with the previous studies that documented the diffraction pattern of AC [45]. The synthesized PM presented several diffraction peaks that were assigned to magnetite $\left(\mathrm{Fe}_{3} \mathrm{O}_{4}\right)$, according to JCPDS sheet no. 190629 . The well-evidenced diffraction peaks were located at 30.10, 35.42, 43.05, 53.39, 56.94 and 62.52 degrees on the 2 theta axis, corresponding to magnetite diffraction planes (220), 
(311), (400), (422), (511) and (440). Based on the XRD analysis, one can conclude that magnetic nanocomposites prepared by combustion synthesis consist of nanocrystalline magnetite incorporated/mixed in an amorphous matrix of activated carbon, which is in total agreement with previous studies carried out on similar themes [45,46].

The crystallite size of magnetite was determined according to the Debye-Scherrer equation (Equation (4)), using the most intense diffraction peak [47]. The obtained crystallite sizes were $6.9 \mathrm{~nm}$ for the PM1 sample, $7.1 \mathrm{~nm}$ for the PM2 sample, $6.4 \mathrm{~nm}$ for the PM3 sample, and $6.2 \mathrm{~nm}$ for the PM4 sample, which indicate that in this case, the surface area of the activated carbon and the thermal treatment time span had no influence on the magnetite crystallite size.

$$
\mathrm{D}=(0.9 \cdot \lambda) /(\beta \cdot \cos \theta)
$$

where $D$ is the crystallite size, $\lambda$ is the $X$-ray wavelength, $\beta$ is the full width at half maximum (FWHM) and $\theta$ is the Bragg angle for the diffraction peak.

\subsubsection{Fourier Transform Infrared (FT-IR) Spectroscopy}

The functional groups present in the synthesized samples and their corresponding frequencies are highlighted in the FT-IR spectra, presented in Figure 2:

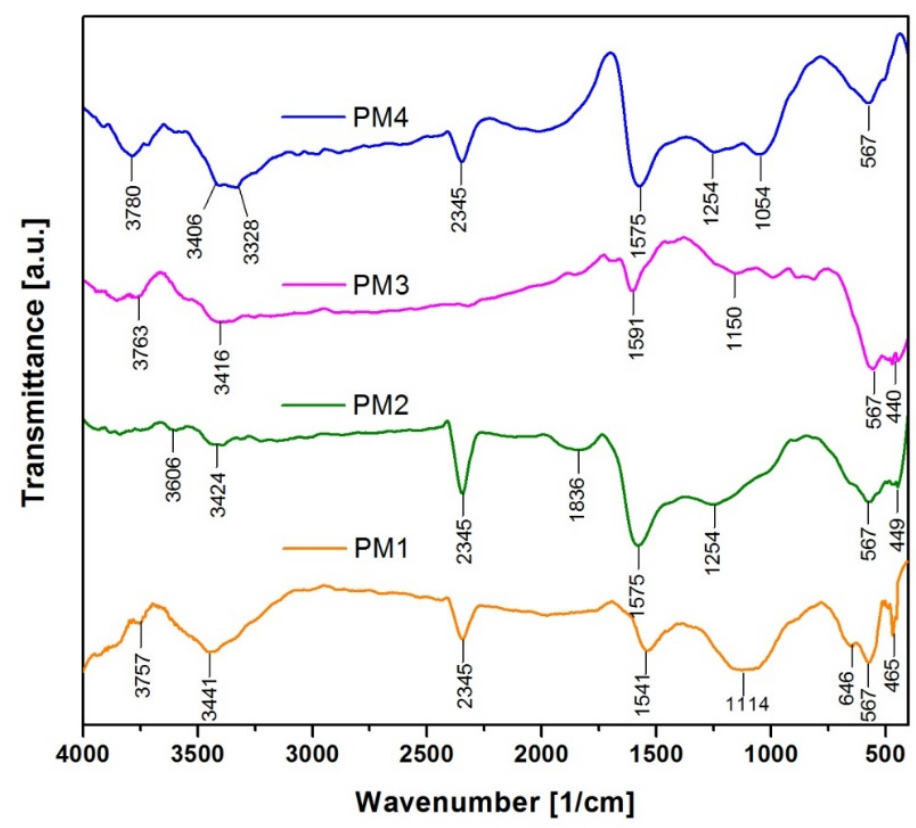

Figure 2. FT-IR spectra of magnetic nanocomposites.

FT-IR analysis indicates the presence of several strong absorption bands located at $465 \mathrm{~cm}^{-1}$ and $567 \mathrm{~cm}^{-1}$ (PM1), $449 \mathrm{~cm}^{-1}$ and $567 \mathrm{~cm}^{-1}$ (PM2), $440 \mathrm{~cm}^{-1}$ and $567 \mathrm{~cm}^{-1}$ (PM3) and $567 \mathrm{~cm}^{-1}$ (PM4), which can be attributed to Fe-O vibration in $\mathrm{Fe}_{3} \mathrm{O}_{4}$, confirming the presence of the magnetite phase [48,49]. This is in total accordance with the results obtained from the X-ray diffraction analysis, namely, the formation of magnetite.

The FT-IR spectra also show some bands due to the organic residues resulting from the combustion reaction. The adsorption bands between $1054 \mathrm{~cm}^{-1}$ and $1254 \mathrm{~cm}^{-1}$ can be attributed to $\mathrm{C}-\mathrm{C}$ and $\mathrm{C}-\mathrm{O}$ stretching vibration in activated carbon [50]. An intense band can be noticed in the range of $1550-1600 \mathrm{~cm}^{-1}$, which is typically attributed to the vibration of $\mathrm{C}=\mathrm{C}$ bonds [51]. The strong absorption bands observed at $2345 \mathrm{~cm}^{-1}$ correspond to chemisorbed $\mathrm{CO}_{2}$ [52]. The adsorption band at $1836 \mathrm{~cm}^{-1}$ found in PM2 is attributed to the stretching vibrations of the $\mathrm{C}=\mathrm{O}$ groups [53]. Adsorption bands were observed in the range $3328-3442 \mathrm{~cm}^{-1}$ in all the spectra, which can be attributed to the stretching vibration of O-H groups coming from the adsorbed water [54]. The small bands identified around 
$3700 \mathrm{~cm}^{-1}$ can also be assigned to the vibrations of the free -OH groups from the surfaces of oxide nanoparticles [55].

\subsubsection{Magnetic Properties of Magnetic Nanocomposites}

The magnetization measurements of the PM1, PM2, PM3 and PM4 nanocomposites recorded at room temperature are presented in Figure 3 and Table 2.

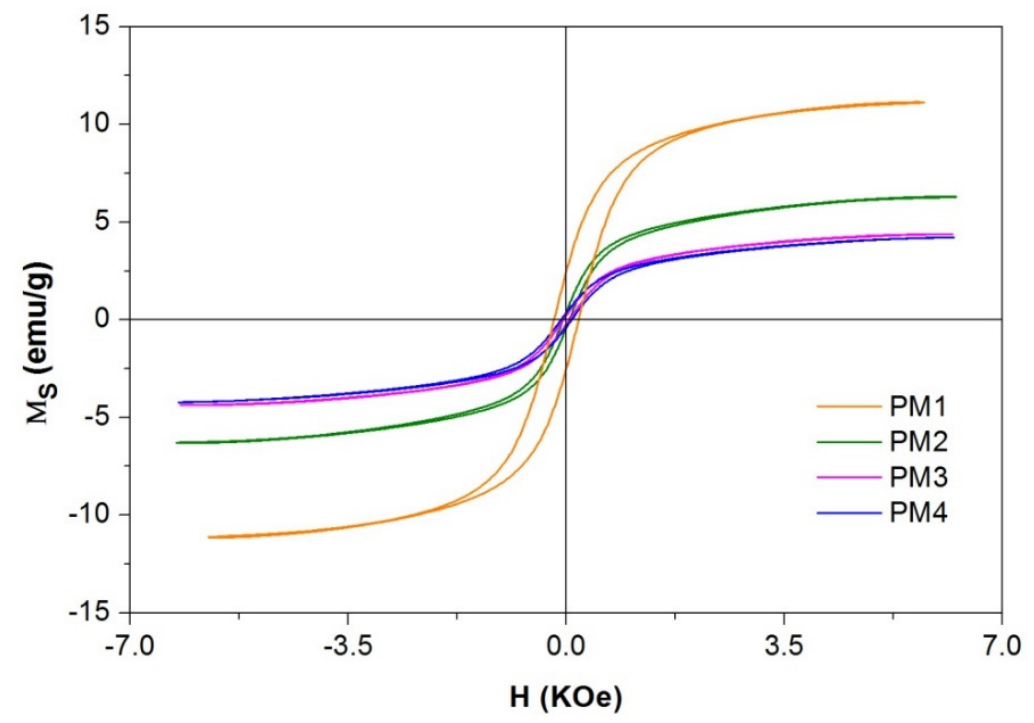

Figure 3. Magnetization curves of magnetic nanocomposites.

Table 2. Magnetic properties of magnetic nanocomposites.

\begin{tabular}{ccccc}
\hline Sample & $\begin{array}{c}\text { Ms } \\
(\mathbf{e m u} / \mathbf{g})\end{array}$ & $\begin{array}{c}\mathbf{H c} \\
\text { (KOe) }\end{array}$ & $\begin{array}{c}\mathbf{M r} \\
(\mathbf{e m u} / \mathbf{g})\end{array}$ & $\begin{array}{c}\mathbf{M r} / \mathbf{M s} \\
(\mathbf{e m u} / \mathbf{g})\end{array}$ \\
\hline PM1 & 13.5 & 0.199 & 2.087 & 0.15 \\
PM2 & 6.94 & 0.051 & 0.401 & 0.05 \\
PM3 & 4.87 & 0.045 & 0.177 & 0.03 \\
PM4 & 4.82 & 0.089 & 0.348 & 0.07 \\
\hline
\end{tabular}

When analyzing the data obtained from the magnetization curves presented in Table 2, one may observe that the saturation magnetization decreases from PM1 to PM3 when AC with a larger specific surface is introduced. The same decreasing trend is observed for the coercive field $(\mathrm{Hc})$ and remanent magnetization $(\mathrm{Mr})$ with the increase in the specific surface of the AC. The decrease in the thermal treatment time from PM3 to PM4 determines a slight decrease in saturation magnetization, but in the case of $\mathrm{Hc}$ and $\mathrm{Mr}$, a doubling of the value can be observed.

The presence of hysteresis in PM1 with a value of coercivity field of 0.2 KOe indicates that the behavior of the material tends to be ferrimagnetic. The squarness ratio of the hysteresis loop (Mr/Ms) specific to samples PM2, PM3 and PM4 indicates a value less than 0.1 , which implies that the materials present superparamagnetic behavior.

The low values of the magnetic measurements are due to the large amount of AC (non-magnetic material) present in the samples, representing $80 \%$ of the entire mass of the samples. Even at these low values of saturation magnetization, the materials still showed very good response to an external magnetic field. This magnetic behavior of the samples will contribute to the easy separation of the adsorbent from the aqueous solution.

\subsection{4. $\mathrm{N}_{2}$ Adsorption-Desorption Isotherms}

Figure 4 presents the $\mathrm{N}_{2}$ adsorption-desorption isotherms for the synthesized magnetic nanocomposites. 


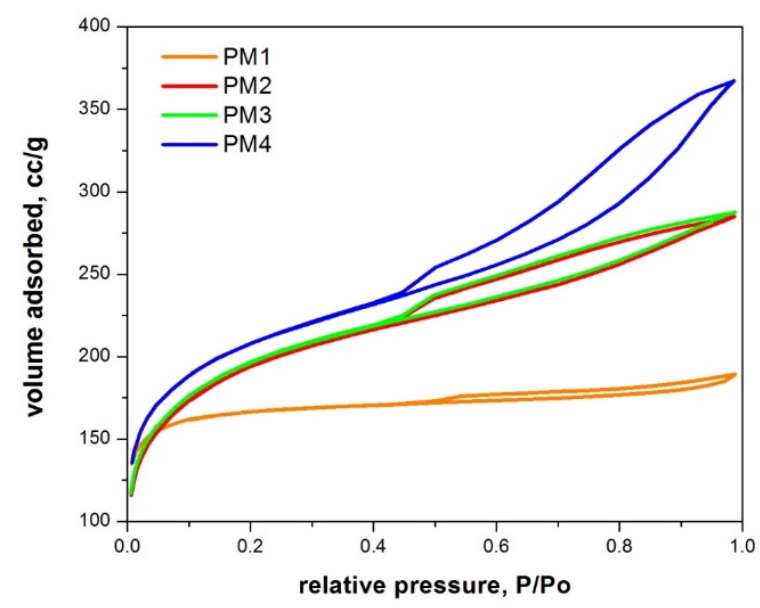

Figure 4. $\mathrm{N}_{2}$ adsorption-desorption isotherms of magnetic nanocomposites.

According to IUPAC classification [56], all magnetic nanocomposites present type IVa adsorption-desorption isotherms with an $\mathrm{H} 4$ hysteresis, indicating that micropores are present.

The pore size distribution of the powders (Figure 5) indicates that all samples exhibit pores with diameters around $3.8 \mathrm{~nm}$.

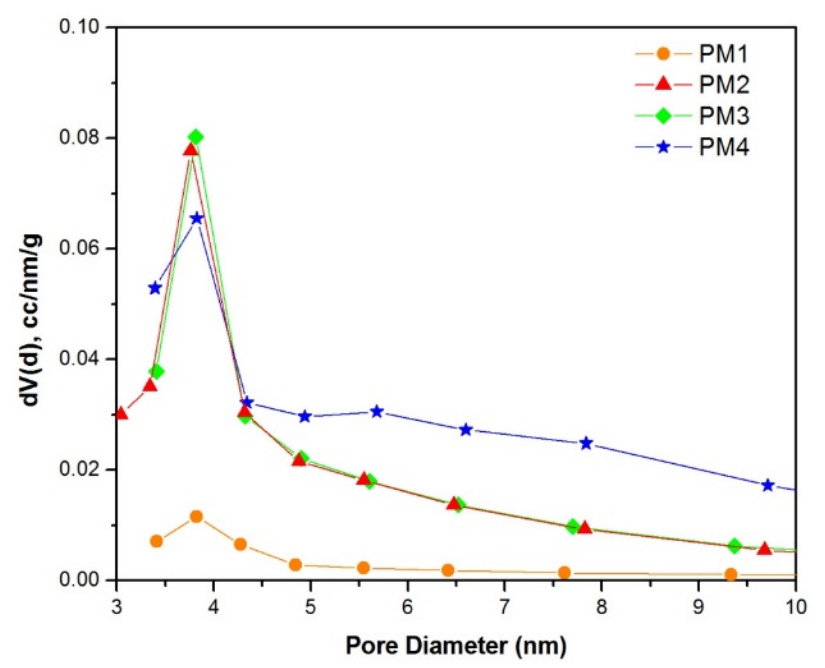

Figure 5. Pore size distribution of magnetic nanocomposites.

Table 3 summarizes the characteristics of the porous structure of magnetic nanocomposites.

Table 3. Characteristics of the magnetic nanocomposites.

\begin{tabular}{|c|c|c|c|c|c|c|}
\hline Sample & $\begin{array}{c}\text { Specific } \\
\text { Surface Area } \\
\left(\mathrm{m}^{2} / \mathrm{g}\right)\end{array}$ & $\begin{array}{l}\text { Total Pore } \\
\text { Volume } \\
\left(\mathrm{cm}^{3} / \mathrm{g}\right)\end{array}$ & $\begin{array}{l}\text { Micropores } \\
\text { Volume } \\
\text { (cc/g) }\end{array}$ & $\begin{array}{c}\text { Micropores } \\
\text { Area } \\
\left(\mathrm{m}^{2} / \mathrm{g}\right)\end{array}$ & $\begin{array}{c}\text { External } \\
\text { Surface Area } \\
\left(\mathrm{m}^{2} / \mathrm{g}\right)\end{array}$ & $\begin{array}{l}\text { Average Pore } \\
\text { Diameter } \\
(\mathrm{nm})\end{array}$ \\
\hline PM1 & 656 & 0.29 & 0.25 & 624.46 & 31.75 & 3.82 \\
\hline PM2 & 708 & 0.44 & 0.22 & 522.68 & 184.89 & 3.76 \\
\hline PM3 & 715 & 0.45 & 0.23 & 531.12 & 183.88 & 3.82 \\
\hline PM4 & 761 & 0.57 & 0.22 & 527.93 & 233.35 & 3.82 \\
\hline
\end{tabular}

The specific surface area of the $\mathrm{AC}$ used as the raw material had a positive effect on the specific surface of the synthesized powders (Table 3). The increase in the specific surface of the AC determined an increase in the specific surface and the total pore volume. At the 
same time, it can be observed that the time span of the thermal treatment determined a change in the specific surface. The reduction in the treatment time from $90 \mathrm{~min}$ (sample PM3) to 60 min (sample PM4) determined a slight increase in the specific surface area, from $715 \mathrm{~m}^{2} / \mathrm{g}$ to $761 \mathrm{~m}^{2} / \mathrm{g}$, which could be explained by the preserving of a larger pore volume.

Due to these characteristics, it is expected that the as-synthesized powders will exhibit excellent adsorption efficiency, especially due to the large specific surface area. In addition, the powders present magnetic properties, which would be an advantage for their separation from aqueous solutions.

\subsubsection{Thermal Analysis of Magnetic Nanocomposites}

The synthesized powders have been characterized by thermal analysis. Figure 6 presents the TG and DSC curves of the prepared samples.

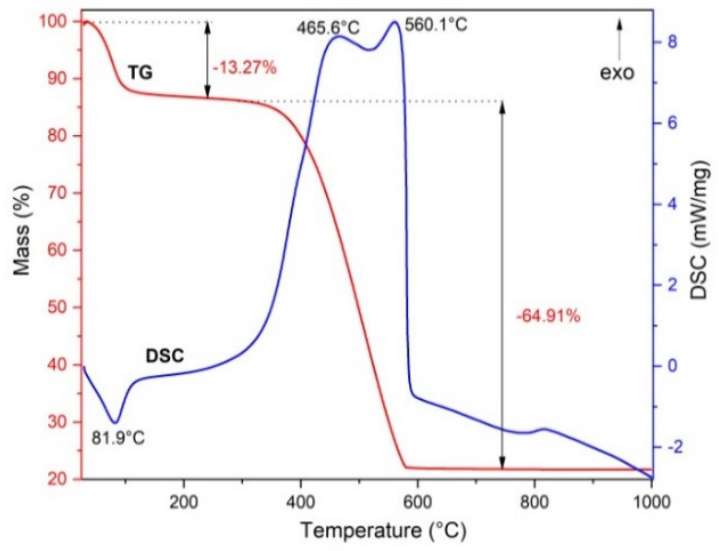

(a)

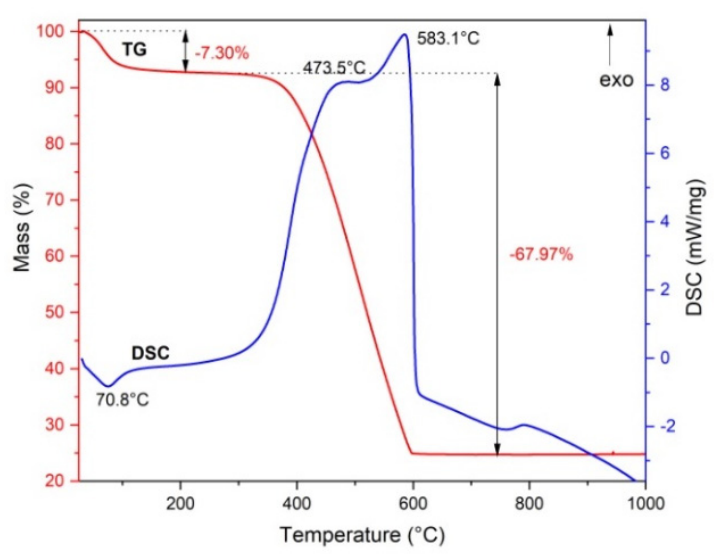

(c)

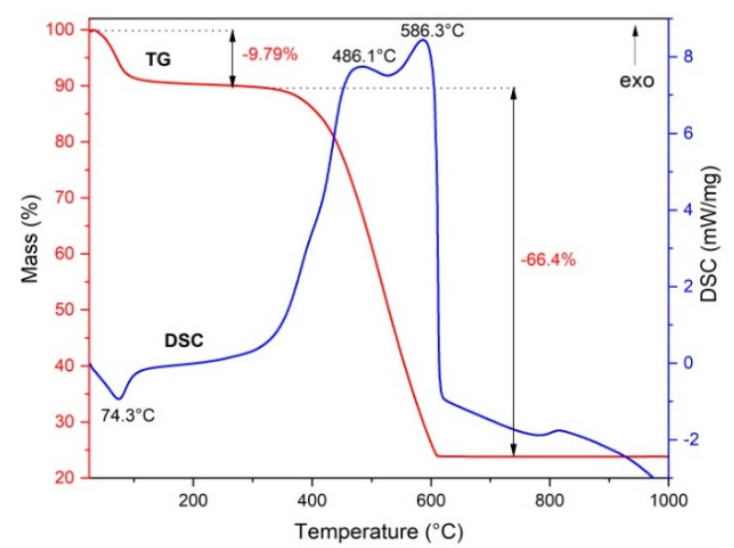

(b)

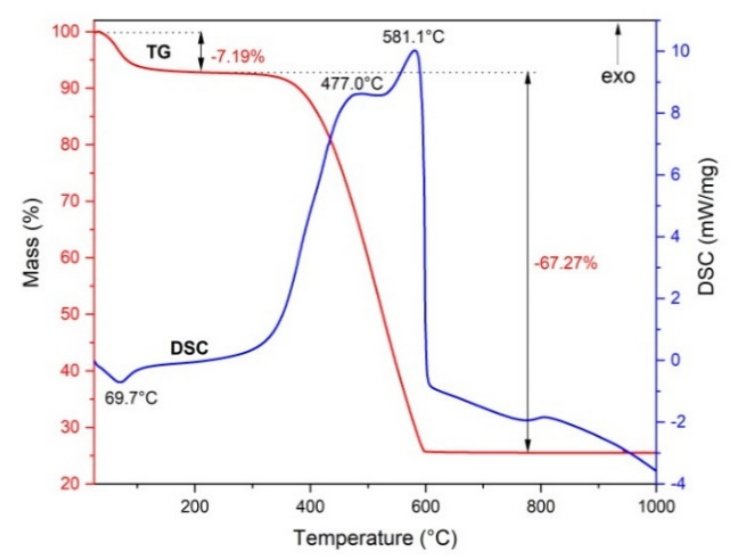

(d)

Figure 6. The TG and DSC curves of magnetic nanocomposites: PM1 (a), PM2 (b), PM3 (c), PM4 (d).

The four samples presented similar behaviors when heated to $1000{ }^{\circ} \mathrm{C}$. The TG curve indicates that all samples exhibited a two-step mass loss. In the first stage, up to $100{ }^{\circ} \mathrm{C}$, the samples underwent a mass loss due to the water removal. This process was accompanied by an endothermic effect, as indicated by the DSC curves. In the first stage, PM1 showed the highest mass loss of $13.27 \%$, followed by PM2 at $9.79 \%$. The other samples showed slightly low losses of $7.30 \%$ for PM3 and $7.19 \%$ for PM4.

In the temperature range of $300-600{ }^{\circ} \mathrm{C}$, the DSC curves for all the samples showed a strong exothermic effect, accompanied by a significant mass loss on the TG curve of about $65-68 \%$. We can see an overlap of two exothermic effects on the DSC curves for all 
investigated samples, attributed to the combustion of the fuel residue and carbon oxidation present in the samples.

\subsubsection{SEM Characterization of Magnetic Nanocomposites}

In terms of morphology, the SEM investigations (Figure 7) do not indicate essential differences between the samples. This may be closely related to the large amount of carbon and the presence of magnetite in all PM samples. The SEM images of the PM evidence the presence of small particles of magnetite with an irregular shape that formed alongside AC.

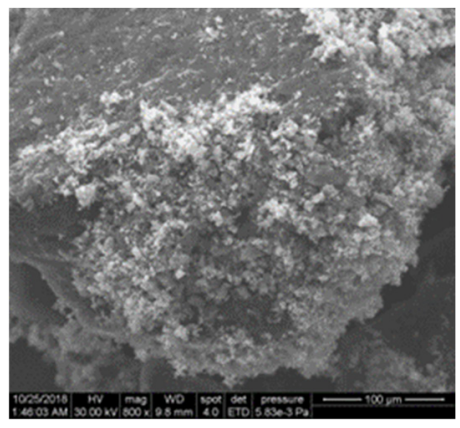

(a)

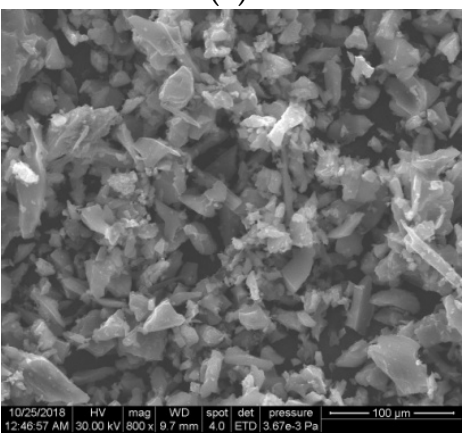

(c)

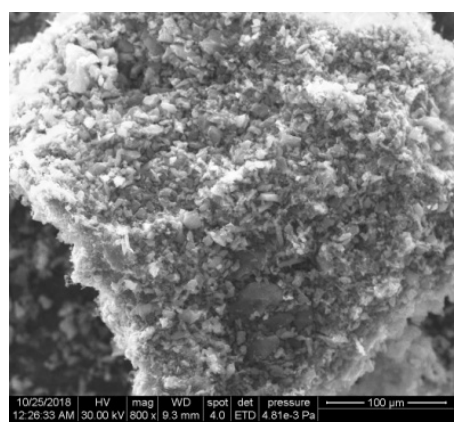

(b)

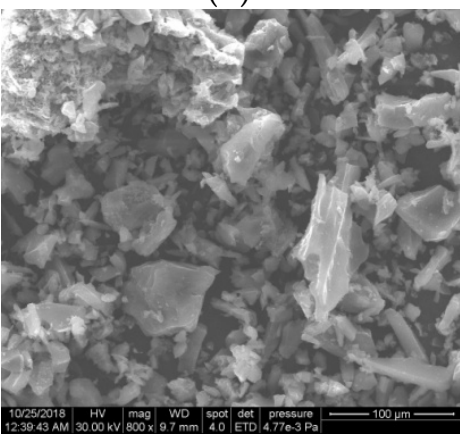

(d)

Figure 7. The SEM images of the magnetic nanocomposites PM1 (a), PM2 (b), PM3 (c) and PM4 (d).

\subsection{Adsorption Experiments}

The molecular structure and characteristics of the anionic dyes Acid Yellow 42 (AY 42) and Acid Red 213 (AR 213) used as adsorbate are presented in Table 4.

Table 4. The molecular structure and characteristics of the investigated dyes.

Dye


The synthesized PMs were tested as adsorbents for the mentioned anionic dyes. The studies were performed at an optimum solution $\mathrm{pH}$ (2.1 for both dyes) and a temperature of $25^{\circ} \mathrm{C}$, using $1 \mathrm{~g} / \mathrm{L} \mathrm{PM}$ and a dye concentration of $50 \mathrm{mg} / \mathrm{L}$. Preliminary adsorption results are presented in Table 5.

Table 5. Removal yields and adsorption capacity of magnetic nanocomposites.

\begin{tabular}{ccccccccc}
\hline & \multicolumn{2}{c}{ PM1 } & \multicolumn{2}{c}{ PM2 } & \multicolumn{2}{c}{ PM3 } & \multicolumn{3}{c}{ PM4 } \\
\hline & $\eta$ & $q_{t}$ & $\eta$ & $q_{t}$ & $\eta$ & $q_{\mathrm{t}}$ & $\eta$ & $q_{t}$ \\
& $(\%)$ & $(\mathrm{mg} / \mathrm{g})$ & $(\%)$ & $(\mathrm{mg} / \mathrm{g})$ & $(\%)$ & $(\mathrm{mg} / \mathrm{g})$ & $(\%)$ & $(\mathrm{mg} / \mathrm{g})$ \\
AY 42 & 64.91 & 33.81 & 79.04 & 39.38 & 80.59 & 40.29 & 98.54 & 49.27 \\
AR 213 & 69.64 & 34.32 & 79.24 & 39.62 & 83.84 & 41.92 & 97.58 & 48.79 \\
\hline
\end{tabular}

The results show that the removal efficiency/adsorption capacity of the magnetic nanocomposites increased from PM1 to PM4, which can be explained by the increase in the specific surface and total pore volume (Table 3). The PM4 sample has been selected as the adsorbent in adsorption studies due to its large specific surface area, high removal efficiency/adsorption capacity, and also because it can achieve good magnetic separation from the aqueous solution.

\subsubsection{Effect of $\mathrm{pH}$ on the Adsorption Process}

The $\mathrm{pH}$ of the solution is considered a very important parameter that affects the adsorption process. In order to determine the optimum $\mathrm{pH}$ value, the analysis was extended by varying the $\mathrm{pH}$ value of the solution in the range 2-12 for the investigated dyes, keeping all other variables constant. The results obtained, presented in Figure 8, indicate a direct relation between the removal efficiency and the $\mathrm{pH}$ of the solution.

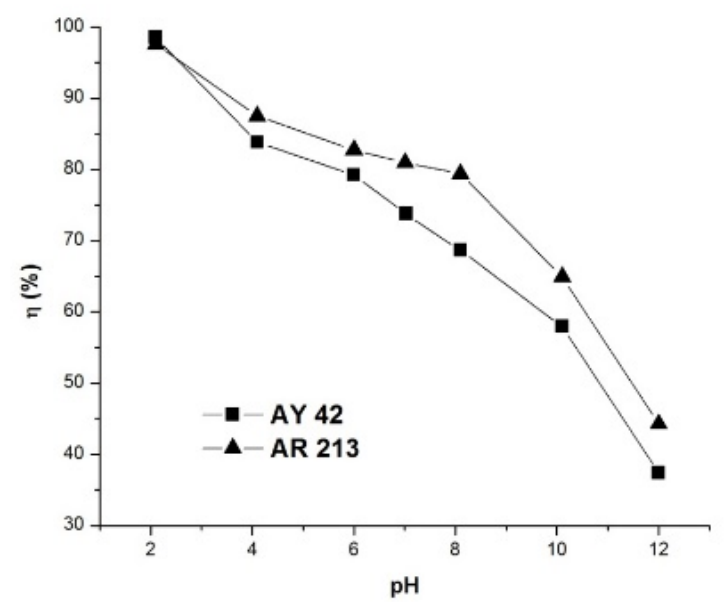

Figure 8. Effect of $\mathrm{pH}$ on dye removal efficiency using PM4; initial dye concentration $50 \mathrm{mg} / \mathrm{L}, 1 \mathrm{~g} / \mathrm{L}$ PM4, contact time $120 \mathrm{~min}, 25^{\circ} \mathrm{C}$.

The removal efficiency of the investigated dyes was high at $\mathrm{pH} 2$, and decreased with the increase in $\mathrm{pH}$ to 12 . This can be explained by the fact that the adsorption mechanism of anionic dyes in acid solution is a result of electrostatic attraction forces between the positively charged surface of the adsorbent and the negatively charged dye molecules [57]. On the other hand, as the $\mathrm{pH}$ increased, the number of hydroxide anions increased, and these compete with anionic dyes for positively charged sites in the adsorbent, which determines a reduction in the removal efficiency as the $\mathrm{pH}$ increases.

The maximum removal yield was obtained at the optimum solution $\mathrm{pH}$ of $\sim 2$ as $98.54 \%$ for AY 42 and $97.58 \%$ in the case of AR 213. It should be noted that the removal efficiencies were higher than $70 \%$, even at the natural $\mathrm{pH}$ of the dye solutions-6.8 for AY 42 and 6.9 for AR 213-so we decided to perform further adsorption studies at a natural $\mathrm{pH}$. 


\subsubsection{Effect of Adsorbent Dose on the Adsorption Process}

To study the influence of the amount of sorbent on the adsorption process, different amounts of PM4 were used $(0.5,1.0$ and $2.0 \mathrm{~g} / \mathrm{L})$, keeping the other variables constant $\left(50 \mathrm{mg} / \mathrm{L}, 25^{\circ} \mathrm{C}\right.$, natural $\mathrm{pH}$ of solution: 6.8 for AY 42 and 6.9 for AR 213). The results are presented in Figure 9. As the amount of adsorbent increased, an increase in dye removal was noticed. These results can be explained by the higher number of active sites available as the adsorbent dose increased, facilitating the adsorption process $[14,58]$.

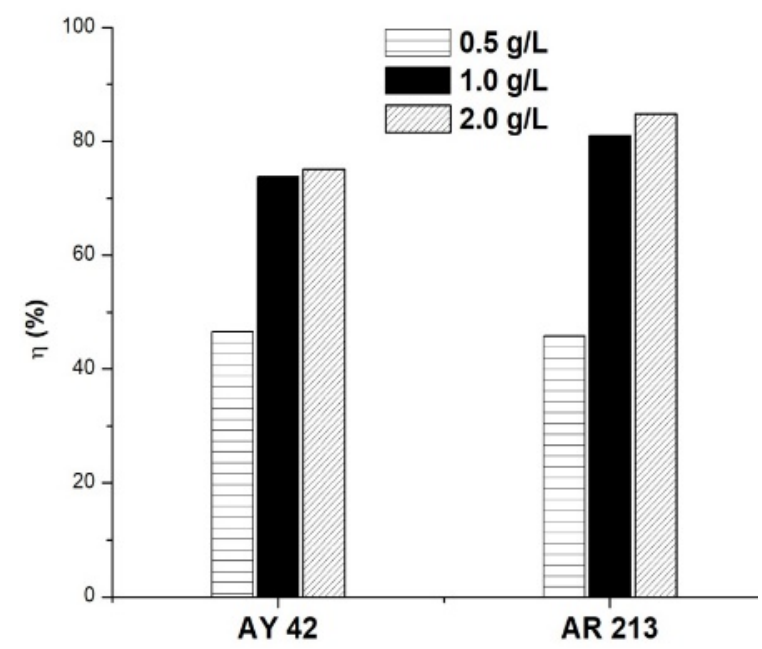

Figure 9. Effect of adsorbent amount on dye removal efficiency using PM4; initial dye concentration $50 \mathrm{mg} / \mathrm{L}, 25^{\circ} \mathrm{C}$, natural $\mathrm{pH}$ of solution.

The removal efficiency of the investigated dyes increased rapidly as the amount of PM4 increased from 0.5 to $1.0 \mathrm{~g} / \mathrm{L}$. An increase in the amount of adsorbent above $1.0 \mathrm{~g} / \mathrm{L}$ did not significantly improve the adsorption of dyes, so it has not been justified for use. In order to obtain a good removal efficiency, using less adsorbent, further studies were performed using $1.0 \mathrm{~g} / \mathrm{L}$ of PM4.

\subsubsection{Effect of Concentration on the Adsorption Process}

The effect of the initial dye concentration on the adsorption capacity was investigated for dye concentrations between 10 and $250 \mathrm{mg} / \mathrm{L}$, at $25^{\circ} \mathrm{C}$ and a natural $\mathrm{pH}$ of the solution. The obtained results are presented in Figure 10 and Table 6.
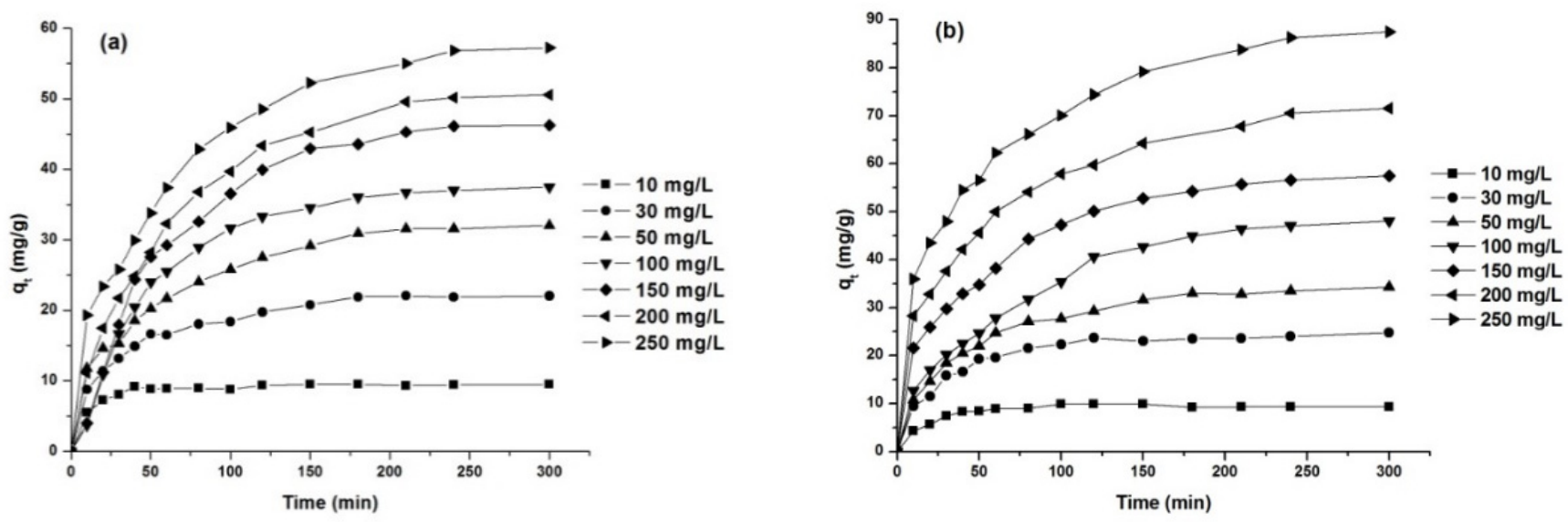

Figure 10. Effect of initial concentration on dye removal capacity: AY 42 (a) and AR 213 (b); $1 \mathrm{~g} / \mathrm{L} \mathrm{PM} 4,25^{\circ} \mathrm{C}$, natural pH of solution. 
Table 6. Influence of the initial concentration of dye solutions on the adsorption capacity of PM4.

\begin{tabular}{ccccc}
\hline \multirow{2}{*}{$\begin{array}{c}\text { Dye Concentration } \\
(\mathbf{m g} / \mathrm{L})\end{array}$} & \multicolumn{2}{c}{ AY 42 } & \multicolumn{2}{c}{ AR 213 } \\
\cline { 2 - 5 } & $\begin{array}{c}\boldsymbol{( \% )} \\
10\end{array}$ & $\begin{array}{c}\boldsymbol{t}_{\boldsymbol{e}} \\
(\mathbf{m i n})\end{array}$ & $\begin{array}{c}\boldsymbol{R} \\
\mathbf{( \% )}\end{array}$ & $\begin{array}{c}\boldsymbol{t}_{\boldsymbol{e}} \\
(\mathbf{m i n})\end{array}$ \\
\hline 30 & 95.01 & 40 & 92.97 & 40 \\
50 & 86.29 & 100 & 90.55 & 60 \\
100 & 73.77 & 160 & 87.53 & 110 \\
150 & 69.76 & 180 & 74.99 & 150 \\
200 & 52.73 & 210 & 55.02 & 170 \\
250 & 38.79 & 250 & 45.53 & 210 \\
\hline
\end{tabular}

As can be seen from Figure 10, the adsorption capacity increased with the increase in initial dye concentration. The adsorption process was fast in the initial stages and remained almost constant after reaching the equilibrium time, due to the saturation of the active centers on the surface of the adsorbent available for the dye $[15,59]$. The time required to reach equilibrium increased with the increasing initial dye concentration (Table 6), because the diffusion in internal adsorption sites was influenced by the increase in the initial dye concentration [60].

\subsubsection{Effect of Temperature on the Adsorption Process}

To investigate the influence of temperature on the adsorption process, three different temperatures were studied $\left(25^{\circ} \mathrm{C}, 45^{\circ} \mathrm{C}\right.$ and $\left.65^{\circ} \mathrm{C}\right)$, working at a concentration of $50 \mathrm{mg} / \mathrm{L}$ and the natural $\mathrm{pH}$ of the solution. The obtained results are presented in Figure 11 and Table 7.

Table 7. Influence of temperature on the adsorption capacity of PM4.

\begin{tabular}{|c|c|c|c|c|}
\hline \multirow{2}{*}{$\begin{array}{c}\text { Temperature } \\
\left({ }^{\circ} \mathrm{C}\right)\end{array}$} & \multicolumn{2}{|c|}{ AY 42} & \multicolumn{2}{|c|}{ AR 213} \\
\hline & $\begin{array}{c}R \\
(\%)\end{array}$ & $\begin{array}{c}t_{e} \\
\text { (min) }\end{array}$ & $\begin{array}{c}R \\
(\%)\end{array}$ & $\begin{array}{c}t_{e} \\
\text { (min) }\end{array}$ \\
\hline 25 & 73.77 & 160 & 87.53 & 110 \\
\hline 45 & 95.84 & 140 & 94.77 & 90 \\
\hline 65 & 98.81 & 100 & 97.86 & 70 \\
\hline
\end{tabular}

The experimental data presented in Figure 11 show that the increase in temperature determined an increase in adsorption capacity, indicating that the adsorption of anionic dyes on PM4 is an endothermic process. This can be explained vie the reduced aggregation of the dye by the increased temperature, facilitating the diffusion of dye molecules into the pores of the adsorbent $[61,62]$. On the other hand, as the temperature increased from 25 to $65{ }^{\circ} \mathrm{C}$, the time required to reach equilibrium decreased from 160 to $100 \mathrm{~min}$ for $\mathrm{AY} 42$, and from 110 to $70 \mathrm{~min}$ for AR 213 (Figure 11, Table 7). High adsorption yields were obtained even at room temperature (Table 7): 73.77\% for AY 24 and 87.53\% for AR 213. 

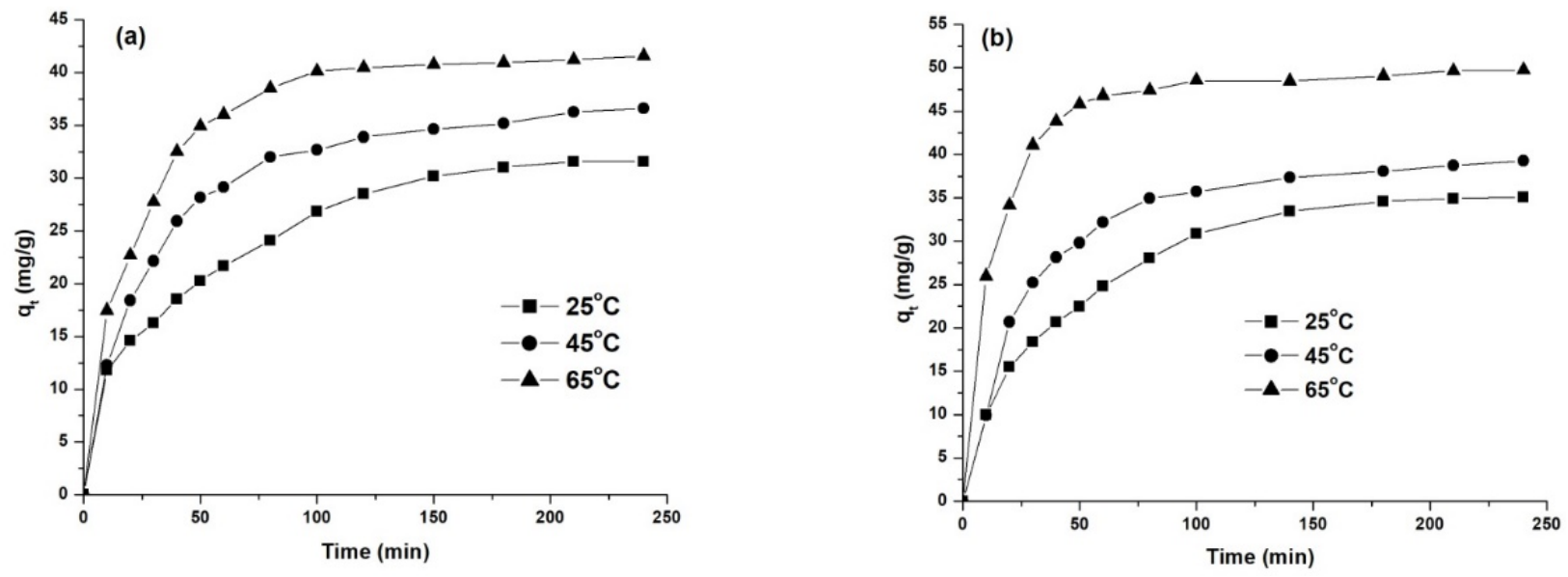

Figure 11. Effect of temperature on dye removal capacity: AY 42 (a) and AR 213 (b); $1 \mathrm{~g} / \mathrm{L} \mathrm{PM} 4,25{ }^{\circ} \mathrm{C}$, natural pH of solution.

\subsection{Kinetic Studies of Adsorption}

Kinetic studies provide information regarding the kinetic parameters and the mechanism of the dye adsorption process. The experimental data obtained at different periods of time for different temperatures were analyzed using the kinetic models pseudo first-order, proposed by Lagergren (Equation (5)) [63], and pseudo second-order, proposed by Ho (Equation (6)) [64].

$$
\begin{gathered}
\ln \left(q_{e}-q_{t}\right)=\ln q_{e}-k_{1} t \\
\frac{t}{q_{t}}=\frac{1}{k_{2} q_{e}^{2}}+\frac{t}{q_{e}}
\end{gathered}
$$

where $q_{e}$ and $q_{t}$ are the amounts of dye adsorbed at equilibrium and at time $\mathrm{t}(\mathrm{mg} / \mathrm{g}), t$ is the contact time $(\mathrm{min}), k_{1}$ is the adsorption rate constant $\left(\mathrm{min}^{-1}\right)$, and $k_{2}$ is the adsorption rate constant $(\mathrm{g} / \mathrm{mg} \cdot \mathrm{min})$.

The kinetic models were fitted using the linear fitting method, and the obtained results are presented in Figures 12 and 13.

The statistical criteria used to determine the best fitting kinetic model were the standard deviation (SD) and the squared multiple regression coefficient $\left(\mathrm{R}^{2}\right)$. The comparison of the experimental adsorption capacity values (obtained at different temperatures) with the computed results estimated from Equations (5) and (6) is presented in Table 8.
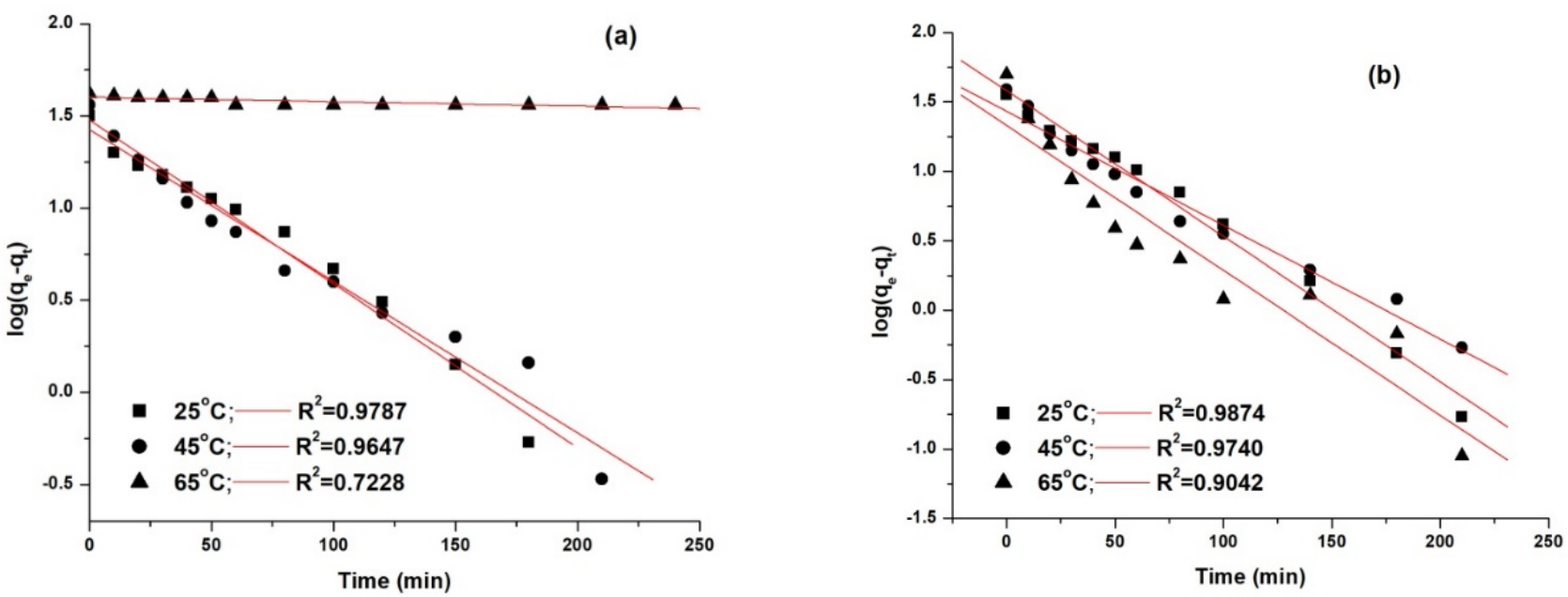

Figure 12. Pseudo first-order kinetic model fitting for the adsorption of AY 42 (a) and AR 213 (b) onto PM4. 

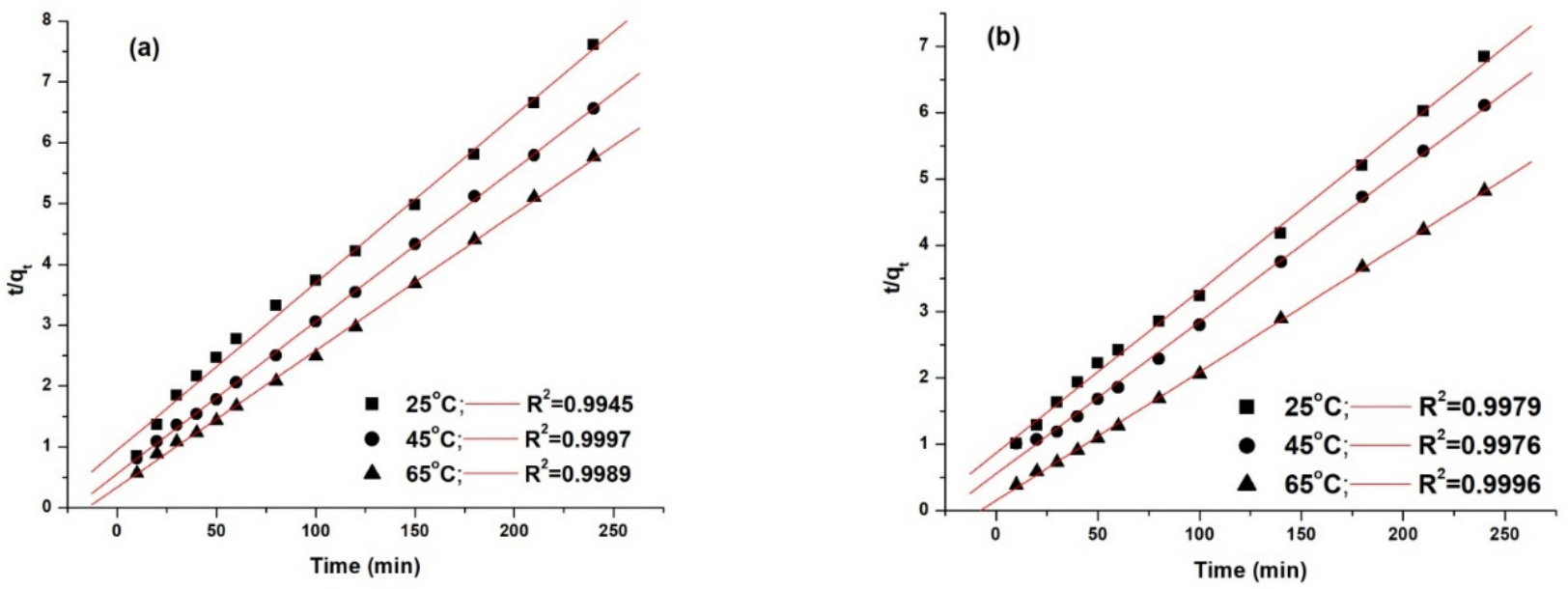

Figure 13. Pseudo second-order kinetic model fitting for the adsorption of AY 42 (a) and AR 213 (b) onto PM4.

Table 8. Kinetic parameters of studied models for adsorption of AY 42 and AR 213 onto PM4.

\begin{tabular}{|c|c|c|c|c|c|c|}
\hline \multirow{2}{*}{ Dye } & \multirow{2}{*}{$\begin{array}{l}\text { Temp. } \\
\left({ }^{\circ} \mathrm{C}\right)\end{array}$} & \multirow{2}{*}{$\begin{array}{c}q_{e, e x p} \\
(\mathrm{mg} / \mathrm{g})\end{array}$} & \multicolumn{2}{|c|}{$\begin{array}{c}\text { Pseudo First-Order Kinetic } \\
\text { Model }\end{array}$} & \multicolumn{2}{|c|}{$\begin{array}{c}\text { Pseudo Second-Order Kinetic } \\
\text { Model }\end{array}$} \\
\hline & & & $\begin{array}{c}q_{e, \text { calc }} \\
(\mathrm{mg} / \mathrm{g})\end{array}$ & $\begin{array}{c}k_{1} 10^{3} \\
\left(\min ^{-1}\right)\end{array}$ & $\begin{array}{l}q_{e, c a l c} \\
(\mathrm{mg} / \mathrm{g})\end{array}$ & $\begin{array}{c}k_{2} 10^{4} \\
(\mathrm{~g} / \mathrm{mg} \cdot \mathrm{min})\end{array}$ \\
\hline \multirow{3}{*}{ AY 42} & 25 & 31.56 & 36.11 & 8.91 & 30.38 & 7.99 \\
\hline & 45 & 36.36 & 26.55 & 8.22 & 39.97 & 11.19 \\
\hline & 65 & 41.57 & 39.95 & 0.24 & 42.50 & 15.03 \\
\hline \multirow{3}{*}{ AR 213} & 25 & 35.08 & 38.08 & 10.48 & 36.82 & 6.91 \\
\hline & 45 & 38.29 & 27.09 & 8.20 & 43.49 & 9.52 \\
\hline & 65 & 49.75 & 21.47 & 10.44 & 51.47 & 24.98 \\
\hline
\end{tabular}

The best model that fitted the experimental data, as shown by the correlation coefficients $\left(\mathrm{R}^{2}\right)$, was the pseudo second-order model. This was highlighted by the concordance between the values of the adsorption capacity determined experimentally $\left(q_{e, \text { exp }}\right)$ and the adsorption capacity calculated $\left(q_{e, \text { calc }}\right)$. As can be seen (Table 8$)$, with an increasing temperature, the pseudo-second rate constant $\mathrm{k}_{2}$ increased, pointing out that the time required to reach the equilibrium decreased with increasing temperature-results that are in agreement with the experimental data.

\subsection{Adsorption Isotherms}

For a better understanding of the adsorption process, we carried out equilibrium adsorption studies. The experimental data obtained at equilibrium were correlated with the equations corresponding to the adsorption models-Freundlich (Equation (7)) [65] and Langmuir (Equation (8)) [66] —in order to establish the optimal model for the adsorption of the investigated dyes from the aqueous solutions.

$$
\begin{gathered}
q_{e}=K_{F} C_{e}^{1 / n} \\
q_{e}=\frac{q_{m} K_{L} C_{e}}{1+K_{L} C_{e}}
\end{gathered}
$$

where $q_{e}$ is the adsorption capacity at equilibrium $(\mathrm{mg} / \mathrm{g}), K_{F}$ is the Freundlich constant $\left(\mathrm{mg} / \mathrm{g}(\mathrm{mg} / \mathrm{L})^{-1 / \mathrm{n}}\right), q_{m}$ is the maximum adsorption capacity of the adsorbent $(\mathrm{mg} / \mathrm{g}), K_{L}$ is the Langmuir affinity constant $(\mathrm{L} / \mathrm{mg}), C_{e}$ is the dye concentration at equilibrium $(\mathrm{mg} / \mathrm{L})$, and $n$ is a constant (dimensionless).

The analysis of the experimental data and the determination of the parameters from the equations that describe the theoretical models were performed by non-linear regression 
analysis. The statistical criteria for choosing the best model that fits with the experimental data were the chi-square analysis and the squared multiple regression coefficient $\left(R^{2}\right)$. The dependence $q_{e}=f\left(C_{e}\right)$ for the adsorption of anionic dyes on PM4 is presented in Figure 14 .
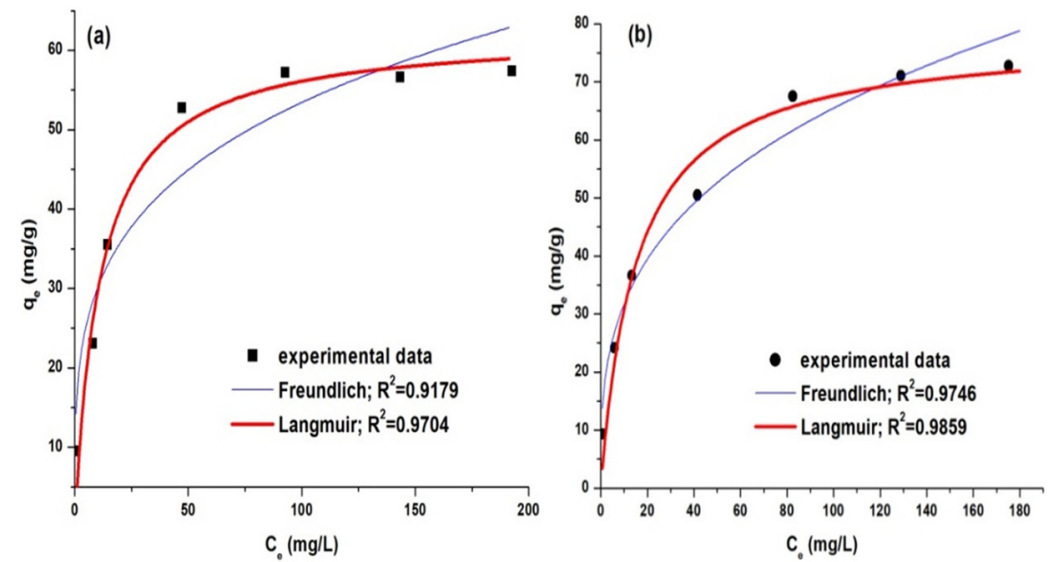

Figure 14. Correlation of experimental data with adsorption isotherms for dye adsorption: AY 42 (a) and AR 213 (b).

The analysis of the statistical data performed on the results obtained indicates that the model that best fits the experimental data is the model described by the Langmuir isotherm. According to this model, the adsorption on PM4's surface is localized, takes place on well-defined specific sites, and is monomolecular with a finite saturation limit. The parameters calculated for the isotherms model are presented in Table 9.

Table 9. Isotherm coefficients for adsorption of AY 24 and AR 213 onto PM4.

\begin{tabular}{cccc}
\hline \multirow{2}{*}{ Models } & Parameter & \multicolumn{2}{c}{ Dyes } \\
\cline { 3 - 4 } & & AY42 & AR213 \\
\hline \multirow{3}{*}{ Freundlich } & $K_{F}\left(\mathrm{mg} / \mathrm{g}(\mathrm{mg} / \mathrm{L})^{-1 / \mathrm{n}}\right)$ & 16.90 & 15.37 \\
& $n$ & 4.011 & 3.177 \\
& $\chi^{2}$ & 36.9719 & 18.9157 \\
Langmuir & $q_{m}(\mathrm{mg} / \mathrm{g})$ & 62.36 & 77.99 \\
& $K_{L}(\mathrm{~L} / \mathrm{mg})$ & 0.089 & 0.065 \\
& $\chi^{2}$ & 13.3303 & 17.9031 \\
\hline
\end{tabular}

From the Langmuir isotherm model, the maximum adsorption capacities of PM4 were determined to be $62.36 \mathrm{mg} / \mathrm{g}$ for AY 42 and $77.99 \mathrm{mg} / \mathrm{g}$ for AR 213. These results attest to the high adsorption capacity of the synthesized PM, an important property for the possible application of these sorbents on a large scale. The values of the maximum adsorption capacity reported in the literature for anionic dyes' adsorption on magnetic nanocomposites are presented in Table 10. The results highlight the better performance obtained in this study.

Table 10. Comparison of the maximum adsorption capacity of anionic dyes onto magnetic nanocomposites.

\begin{tabular}{|c|c|c|c|}
\hline Adsorbent. & Dye & $q_{m}(\mathrm{mg} / \mathrm{g})$ & Reference \\
\hline $\mathrm{NiFe}_{2} \mathrm{O}_{4}$ magnetic nanoparticles & Eriochrome black-T & 47 & [67] \\
\hline Fe@graphite core-shell nanocomposite & $\begin{array}{c}\text { Acid Red } 88 \\
\text { Direct Orange } 26\end{array}$ & $\begin{array}{l}41.8 \\
28.3\end{array}$ & [68] \\
\hline $\mathrm{Fe}_{3} \mathrm{O}_{4}$ supported chitosan-graphene oxide composite & Alizarin yellow $\mathrm{R}$ & 14.82 & [69] \\
\hline Magnetic $\mathrm{Fe}_{3} \mathrm{O}_{4} @$ graphene composite & Congo Red & 33.66 & [70] \\
\hline Activated carbon coated by zinc oxide nanoparticles & Acid Orange 7 & 66.22 & {$[71]$} \\
\hline
\end{tabular}


Table 10. Cont.

\begin{tabular}{|c|c|c|c|}
\hline Adsorbent. & Dye & $q_{m}(\mathrm{mg} / \mathrm{g})$ & Reference \\
\hline Magnetic ferrite nanoparticle & $\begin{array}{l}\text { Direct Red } 23 \\
\text { Direct Red } 31\end{array}$ & $\begin{array}{l}26.11 \\
55.56\end{array}$ & {$[72]$} \\
\hline Magnetic iron oxide nanopowder & Congo Red & 54.46 & [73] \\
\hline Magnetic nanocomposites & $\begin{array}{l}\text { Acid Yellow } 42 \\
\text { Acid Red } 213\end{array}$ & $\begin{array}{l}62.36 \\
77.99\end{array}$ & This work \\
\hline
\end{tabular}

\subsection{Thermodynamics of the Adsorption Process}

The main thermodynamic parameters (free energy $\left(\Delta G^{\circ}\right)$, enthalpy $\left(\Delta H^{\circ}\right)$ and entropy $\left.\left(\Delta S^{\circ}\right)\right)$ for the adsorption process of AY 42 and AR 213 dyes were calculated using the results obtained for the Langmuir model.

The Gibb's free energy $\left(\Delta G^{\circ}\right)$ was calculated using the Equation (9),

$$
\Delta G^{0}=-R T \ln K_{L}
$$

and the enthalpy $\left(\Delta H^{\circ}\right)$ and entropy $\left(\Delta S^{\circ}\right)$ values for adsorption process were determined from the van't Hoff Equation (10),

$$
\Delta G^{0}=\Delta H^{0}-T \Delta S^{0}
$$

where $R$ is the general gas constant $(8.314 \mathrm{~J} / \mathrm{Kmol}), T$ is the absolute temperature and $K_{L}$ is the Langmuir adsorption constant, obtained from the isotherm plots. The $\Delta H^{\circ}$ and $\Delta S^{\circ}$ parameters were evaluated from the slope and intercept of the linear plot of $\Delta G^{\circ}$ versus $T$.

The results obtained for thermodynamic parameters are presented in Table 11.

Table 11. Thermodynamic parameters for the adsorption of the investigated dyes on PM4.

\begin{tabular}{ccccc}
\hline Dye & $\begin{array}{c}\text { Temp. } \\
\left({ }^{\circ} \mathbf{C}\right)\end{array}$ & $\begin{array}{c}\Delta G^{\circ} \\
(\mathbf{J} / \mathbf{m o l})\end{array}$ & $\begin{array}{c}\Delta \boldsymbol{H}^{\circ} \\
(\mathbf{J} / \mathbf{m o l})\end{array}$ & $\begin{array}{c}\Delta \boldsymbol{S}^{\circ} \\
(\mathrm{J} / \mathbf{m o l} \cdot \mathbf{K})\end{array}$ \\
\hline & 25 & -5969.99 & & \\
AY42 & 45 & -6370.66 & 4767.98 & -400.67 \\
& 65 & -6771.33 & & \\
AR213 & 25 & -6765.64 & & -454.07 \\
& 45 & -7219.71 & 5403.43 & \\
\hline
\end{tabular}

The negative values of Gibb's free energy $\left(\Delta G^{\circ}\right)$ indicate that the adsorption process of the AY 42 and AR 213 dyes from aqueous solutions on PM4 was spontaneous [74]. The positive values of the enthalpy variation $\left(\Delta H^{\circ}\right)$ reveal the endothermic nature of the adsorption process, and confirm the experimental results obtained from the influence of temperature study, which indicate that the adsorption capacity increases with increasing temperature [75]. The negative values of the entropy variation $\left(\Delta S^{\circ}\right)$ that characterize the adsorption process suggest that the dye molecules decrease their randomness at the solid-liquid interface during the adsorption [76].

\section{Conclusions}

In this study, magnetic nanocomposites have been successfully prepared by a simple combustion method, confirmed by XRD, FT-IR spectroscopy, magnetic properties, $\mathrm{N}_{2}$ adsorption-desorption, TG/DSC and SEM analyses, and applied as an adsorbent for the removal of two anionic dyes (AY 42 and AR 213) from aqueous solutions. The removal efficiency of the investigated dyes decreased with an increase in the $\mathrm{pH}$ and increased with increasing adsorbent doses, initial dye concentrations and temperatures. The adsorption process can be performed under normal conditions (room temperature $\left(25^{\circ} \mathrm{C}\right)$ and natural 
solution $\mathrm{pH}$ (6.8 for AY 42 and 6.9 for AR 213)), which is important for possible large-scale applications. Kinetic studies revealed that the pseudo second-order model can better fit the experimental data, and the Langmuir isotherm model describes the adsorption process. The maximum adsorption capacity determined by the Langmuir model was $62.36 \mathrm{mg} / \mathrm{g}$ for AY 42 and $77.99 \mathrm{mg} / \mathrm{g}$ for AR 213, and the maximum removal efficiencies obtained under the optimum working conditions were $98.54 \%$ for AY 42 and $97.58 \%$ for AR 213 . The thermodynamic parameters indicate that the adsorption of the anionic investigated dyes was a spontaneous and endothermic process, due to the positive $\Delta H^{\circ}$ values and negative $\Delta G^{\circ}$ values at the various temperatures investigated. The facile and economic synthesis method for adsorbents, which has a high adsorption capacity and magnetic separation efficiency, indicates that the as-prepared magnetic nanocomposites are promising adsorbent materials for the removal of dyes from aqueous solutions.

Author Contributions: Conceptualization, S.G.M. and L.C.; synthesis: M.-A.N. and R.I.; structural characterization: M.-A.N.; XRD: R.I.; FT-IR: R.R.; nitrogen adsorption-desorption: C.I.; adsorption studies: M.-A.N. and S.G.M.; supervision: S.G.M. and L.C.; writing-original draft preparation, M.-A.N., and R.R.; writing - review and editing, R.I. and S.G.M. All authors have read and agreed to the published version of the manuscript.

Funding: This research received no external funding.

Institutional Review Board Statement: Not applicable.

Informed Consent Statement: Not applicable.

Data Availability Statement: All the data is available within this manuscript.

Acknowledgments: This work was supported by Program No. 2 of "Coriolan Drăgulescu" Institute of Chemistry. The authors would like to thank Aurel Ercuta from West University of Timisoara, Romania for magnetic measurements, Cornelia Pacurariu from Politehnica University Timișoara for TG/DSC analysis, and Paula Sfârloagă from National Institute for Research and Development in Electrochemistry and Condensed Matter, Timisoara for the SEM analyses for investigated magnetic nanocomposite.

Conflicts of Interest: The authors declare no conflict of interest.

\section{References}

1. Mani, S.; Chowdhary, P.; Bharagava, R.N. Chapter 11: Textile Wastewater Dyes: Toxicity Profile and Treatment Approaches. In Emerging and Eco-Friendly Approaches for Waste Management; Bharagava, R.N., Chowdhary, P., Eds.; Springer Nature Singapore Pte Ltd.: Singapore, 2019; pp. 219-244. [CrossRef]

2. Samsami, S.; Mohamadizaniani, M.; Sarrafzadeh, M.-H.; Rene, E.R.; Firoozbahr, M. Recent advances in the treatment of dyecontaining wastewater from textile industries: Overview and perspectives. Process. Saf. Environ. Prot. 2020, 143, $138-163$. [CrossRef]

3. Lellis, B.; Fávaro-Polonio, C.Z.; Pamphile, J.A.; Polonio, J.C. Effects of textile dyes on health and the environment and bioremediation potential of living organisms. Biotechnol. Res. Innov. 2019, 3, 275-290. [CrossRef]

4. Pereira, L.; Alves, M. Chapter 4: Dyes-Environmental Impact and Remediation. In Environmental Protection Strategies for Sustainable Development, Strategies for Sustainability; Malik, A., Grohmann, E., Eds.; Springer Science + Business Media B.V.: Dordrecht, The Netherlands, 2012; pp. 111-154.

5. Al Prol, A.E. Study of Environmental Concerns of Dyes and Recent Textile Effluents Treatment Technology: A Review. Asian J. Fish. Aquat. Res. 2019, 1-18. [CrossRef]

6. Toprak, T.; Anis, P. Textile Industry's Environmental Effects and Approaching Cleaner Production and Sustainability: An Overview. J. Text. Eng. Fash. Technol. 2017, 2, 1-16. [CrossRef]

7. An, S.; Liu, X.; Yang, L.; Zhang, L. Enhancement removal of crystal violet dye using magnetic calcium ferrite nanoparticle: Study in single- and binary-solute systems. Chem. Eng. Res. Des. 2014, 94, 726-735. [CrossRef]

8. Yang, S.; Wu, Z.; Huang, L.; Zhou, B.; Lei, M.; Sun, L.; Tian, Q.; Pan, J.; Wu, W.; Zhang, H. Significantly enhanced dye removal performance of hollow tin oxide nanoparticles via carbon coating in dark environment and study of its mechanism. Nanoscale Res. Lett. 2014, 9, 442. [CrossRef]

9. Zhou, Z.; Lin, S.; Yue, T.; Lee, T.-C. Adsorption of food dyes from aqueous solution by glutaraldehyde cross-linked magnetic chitosan nanoparticles. J. Food Eng. 2014, 126, 133-141. [CrossRef]

10. Mohamed, A.H.; Ahmed El, N. Health and Environmental Impacts of Dyes: Mini Review. Am. J. Environ. Sci. 2017, 1, 64-67. [CrossRef] 
11. Manzoor, J.; Sharma, M. Chapter 8: Impact of Textile Dyes on Human Health and Environment. In Impact of Textile Dyes on Public Health and the Environment; IGI Global: Hershey, PA, USA, 2020; pp. 162-170.

12. Ismail, M.; Akhtar, K.; Khan, M.; Kamal, T.; Asiri, A.M.; Seo, J.; Khan, S.B. Pollution, Toxicity and Carcinogenicity of Organic Dyes and their Catalytic Bio-Remediation. Curr. Pharm. Des. 2019, 25, 3645-3663. [CrossRef]

13. Katheresan, V.; Kansedo, J.; Lau, S.Y. Efficiency of various recent wastewater dye removal methods: A review. J. Environ. Chem. Eng. 2018, 6, 4676-4697. [CrossRef]

14. Muntean, S.G.; Nistor, M.A.; Muntean, E.; Todea, A.; Ianoș, R.; Păcurariu, C. Removal of Colored Organic Pollutants from Wastewaters by Magnetite/Carbon Nanocomposites: Single and Binary Systems. J. Chem. 2018, 2018, 1-16. [CrossRef]

15. Kuang, Y.; Zhang, X.; Zhou, S. Adsorption of Methylene Blue in Water onto Activated Carbon by Surfactant Modification. Water 2020, 12, 587. [CrossRef]

16. Yagub, M.T.; Sen, T.K.; Afroze, S.; Ang, H. Dye and its removal from aqueous solution by adsorption: A review. Adv. Colloid Interface Sci. 2014, 209, 172-184. [CrossRef] [PubMed]

17. Garrido-Cardenas, J.A.; Esteban-García, B.; Agüera, A.; Sánchez-Pérez, J.A.; Manzano-Agugliaro, F. Wastewater Treatment by Advanced Oxidation Process and Their Worldwide Research Trends. Int. J. Environ. Res. Public Health 2019, 17, 170. [CrossRef]

18. Lin, L.; Jiang, W.; Chen, L.; Xu, P.; Wang, H. Treatment of Produced Water with Photocatalysis: Recent Advances, Affecting Factors and Future Research Prospects. Catalysts 2020, 10, 924. [CrossRef]

19. Rashidi, H.R.; Sulaiman, N.M.N.; Hashim, N.A.; Hassan, C.R.C.; Ramli, M.R. Synthetic reactive dye wastewater treatment by using nano-membrane filtration. Desalin. Water Treat. 2014, 55, 86-95. [CrossRef]

20. Das, K.C.; Das, B.; Dhar, S.S. Effective Catalytic Degradation of Organic Dyes by Nickel Supported on HydroxyapatiteEncapsulated Cobalt Ferrite (Ni/HAP/CoFe2O4) Magnetic Novel Nanocomposite. Water Air Soil Pollut. 2020, $231,1-13$. [CrossRef]

21. Gadekar, M.R.; Ahammed, M.M. Coagulation/flocculation process for dye removal using water treatment residuals: Modelling through artificial neural networks. Desalin. Water Treat. 2016, 57, 26392-26400. [CrossRef]

22. Abid, M.F.; Zablouk, M.A.; Abid-Alameer, A.M. Experimental study of dye removal from industrial wastewater by membrane technologies of reverse osmosis and nanofiltration. Iran. J. Environ. Health Sci. Eng. 2012, 9, 17. [CrossRef] [PubMed]

23. Jamee, R.; Siddique, R. Biodegradation of synthetic dyes of textile effluent by microorganisms: An environmentally and economically sustainable approach. Eur. J. Microbiol. Immunol. 2019, 9, 114-118. [CrossRef]

24. Crini, G.; Lichtfouse, E. Advantages and disadvantages of techniques used for wastewater treatment. Environ. Chem. Lett. 2018, 17, 145-155. [CrossRef]

25. Crini, G.; Lichtfouse, E. Chapter1: Wastewater Treatment: An Overview. In Green Adsorbents for Pollutant Removal, Environmental Chemistry for a Sustainable World; Springer Nature: Cham, Switzerland, 2018; Volume 18, pp. 1-21. [CrossRef]

26. Corda, N.C.; Kini, M.S. A Review on Adsorption of Cationic Dyes using Activated Carbon. MATEC Web Conf. $2018,144,02022$. [CrossRef]

27. Abukhadra, M.R.; Mohamed, A.S. Adsorption Removal of Safranin Dye Contaminants from Water Using Various Types of Natural Zeolite. Silicon 2018, 11, 1635-1647. [CrossRef]

28. Nicola, R.; Costişor, O.; Muntean, S.G.; Nistor, M.-A.; Putz, A.-M.; Ianăşi, C.; Lazău, R.; Almasy, L.; Săcărescu, L. Mesoporous magnetic nanocomposites: A promising adsorbent for the removal of dyes from aqueous solutions. J. Porous Mater. 2019, 27, 413-428. [CrossRef]

29. Nistor, M.A.; Muntean, S.G.; Maranescu, B.; Visa, A. Phosphonate metal-organic frameworks used as dye removal materials from wastewaters. Appl. Organomet. Chem. 2020, 34. [CrossRef]

30. Şen, F.; Demirbaş, Ö.; Çalımlı, M.H.; Aygun, A.; Alma, M.H.; Nas, M.S. The dye removal from aqueous solution using polymer composite films. Appl. Water Sci. 2018, 8, 206. [CrossRef]

31. Adegoke, K.A.; Bello, O.S. Dye sequestration using agricultural wastes as adsorbents. Water Resour. Ind. 2015, 12, 8-24. [CrossRef]

32. Ge, M.; Xi, Z.; Zhu, C.; Liang, G.; Hu, G.; Jamal, L.; Alam, S.M.J. Preparation and Characterization of Magadiite-Magnetite Nanocomposite with Its Sorption Performance Analyses on Removal of Methylene Blue from Aqueous Solutions. Polymers 2019, 11, 607. [CrossRef] [PubMed]

33. Ianos, R.; Păcurariu, C.; Muntean, S.G.; Muntean, E.; Nistor, M.A.; Nižňanský, D. Combustion synthesis of iron oxide/carbon nanocomposites, efficient adsorbents for anionic and cationic dyes removal from wastewaters. J. Alloy. Compd. 2018, 741, 1235-1246. [CrossRef]

34. Liu, Y.; Huang, Y.; Xiao, A.; Qiu, H.; Liu, L. Preparation of Magnetic Fe3O4/MIL-88A Nanocomposite and Its Adsorption Properties for Bromophenol Blue Dye in Aqueous Solution. Nanomaterials 2019, 9, 51. [CrossRef]

35. Muntean, S.G.; Nistor, M.A.; Ianos, R.; Păcurariu, C.; Căpraru, A.; Surdu, V.-A. Combustion synthesis of Fe3O4/ Ag/C nanocomposite and application for dyes removal from multicomponent systems. Appl. Surf. Sci. 2019, 481, 825-837. [CrossRef]

36. Parashar, M.; Shukla, V.K.; Singh, R. Metal oxides nanoparticles via sol-gel method: A review on synthesis, characterization and applications. J. Mater. Sci. Mater. Electron. 2020, 31, 3729-3749. [CrossRef]

37. Luo, S.; Wang, R.; Yin, J.; Jiao, T.; Chen, K.; Zou, G.; Zhang, L.; Zhou, J.; Zhang, L.; Peng, Q. Preparation and Dye Degradation Performances of Self-Assembled MXene-Co3O4 Nanocomposites Synthesized via Solvothermal Approach. ACS Omega 2019, 4, 3946-3953. [CrossRef] 
38. Chen, M.; Shao, L.-L.; Li, J.-J.; Pei, W.-J.; Chen, M.-K.; Xie, X.-H. One-step hydrothermal synthesis of hydrophilic Fe3O4/carbon composites and their application in removing toxic chemicals. RSC Adv. 2016, 6, 35228-35238. [CrossRef]

39. Alotaibi, N.; Hammud, H.H.; Karnati, R.K.; Hussain, S.G.; Mazher, J.; Prakasam, T. Cobalt-carbon/silica nanocomposites prepared by pyrolysis of a cobalt 2,2'-bipyridine terephthalate complex for remediation of cationic dyes. RSC Adv. 2020, 10, 17660-17672. [CrossRef]

40. Yazdani, F.; Seddigh, M. Magnetite nanoparticles synthesized by co-precipitation method: The effects of various iron anions on specifications. Mater. Chem. Phys. 2016, 184, 318-323. [CrossRef]

41. Păcurariu, C.; Paşka, O.; Ianoş, R.; Muntean, S.G. Effective removal of methylene blue from aqueous solution using a new magnetic iron oxide nanosorbent prepared by combustion synthesis. Clean Technol. Environ. Policy 2015, 18, 705-715. [CrossRef]

42. Ianos, R.; Păcurariu, C.; Mihoc, G. Magnetite/carbon nanocomposites prepared by an innovative combustion synthesis techniqueExcellent adsorbent materials. Ceram. Int. 2014, 40, 13649-13657. [CrossRef]

43. Mihoc, G.; Ianos, R.; Păcurariu, C.; Lazău, I. Combustion synthesis of some iron oxides used as adsorbents for phenol and p-chlorophenol removal from wastewater. J. Therm. Anal. Calorim. 2012, 112, 391-397. [CrossRef]

44. Ercuta, A.; Chirita, M. Highly crystalline porous magnetite and vacancy-ordered maghemite microcrystals of rhombohedral habit. J. Cryst. Growth 2013, 380, 182-186. [CrossRef]

45. Rodrigues, S.C.; Silva, M.C.; Torres, J.A.; Bianchi, M.L. Use of Magnetic Activated Carbon in a Solid Phase Extraction Procedure for Analysis of 2,4-dichlorophenol in Water Samples. Water Air Soil Pollut. 2020, 231, 1-13. [CrossRef]

46. Torres, J.; Silva, M.; Lopes, J.H.; Nogueira, A.; Nogueira, F.; Corrêa, A. Development of a reusable and sustainable biocatalyst by immobilization of soybean peroxidase onto magnetic adsorbent. Int. J. Biol. Macromol. 2018, 114, 1279-1287. [CrossRef]

47. Amargeetha, A.; Velavan, S. X-ray Diffraction (XRD) and Energy Dispersive Spectroscopy (EDS) Analysis of Silver Nanoparticles Synthesized from Erythrina Indica Flowers. Nanosci. Technol. Open Access 2018, 5, 1-5. [CrossRef]

48. Liese, H.C. Mineralogical notes. An infrared absorption analysis of magnetite. Am. Mineral. 1967, 52, $1198-1205$.

49. Kim, K.D.; Kim, S.S.; Choa, Y.H.; Kim, H.T. Formation and surface modification of Fe3O4 nanoparticles by co-precipitation and sol-gel method. J. Ind. Eng. Chem. 2007, 13, 1137-1141.

50. Kahani, S.A.; Hamadanian, M.; Vandadi, O. Deposition of Magnetite Nanoparticles in Activated Carbons and Preparation of Magnetic Activated Carbons. AIP Conf. Proc. 2007, 929, 183-188. [CrossRef]

51. Fuente, E.; Menéndez, J.A.; Diez, M.A.; Suarez, D.; Montes-Moran, M.A. Infrared Spectroscopy of Carbon Materials: A Quantum Chemical Study of Model Compounds. J. Phys. Chem. B 2003, 107, 6350-6359. [CrossRef]

52. Yang, C.; Wöll, C. IR spectroscopy applied to metal oxide surfaces: Adsorbate vibrations and beyond. Adv. Phy. X 2017, 2, 373-408. [CrossRef]

53. Li, Y.-S.; Church, J.S.; Woodhead, A. Infrared and Raman spectroscopic studies on iron oxide magnetic nano-particles and their surface modifications. J. Magn. Magn. Mater. 2012, 324, 1543-1550. [CrossRef]

54. Shepel, D.; Goreacioc, T.; Lupascu, T.; Filippov, M.; Rusu, M. Method of Infrared Spectra Registration of Activated Carbons in Potassium Bromide Pellets. Chem. J. Mold. 2015, 10, 113-115. [CrossRef]

55. Zawadzki, J. Infrared spectroscopy in surface chemistry of carbons. In Chemistry and Physics of Carbon; Thrower, P.A., Ed.; Marcel Dekker: New York, NY, USA, 1989; Volume 21, pp. 147-380.

56. Thommes, M.; Kaneko, K.; Neimark, A.V.; Olivier, J.P.; Rodriguez-Reinoso, F.; Rouquerol, J.; Sing, K.S. Physisorption of gases, with special reference to the evaluation of surface area and pore size distribution (IUPAC Technical Report). Pure Appl. Chem. 2015, 87, 1051-1069. [CrossRef]

57. Alhujaily, A.; Yu, H.; Zhang, X.; Ma, F. Adsorptive removal of anionic dyes from aqueous solutions using spent mushroom waste. Appl. Water Sci. 2020, 10, 1-12. [CrossRef]

58. Nazir, R.; Khan, M.; Rehman, R.U.; Shujah, S.; Khan, M.; Ullah, M.; Zada, A.; Mahmood, N.; Ahmad, I. Adsorption of selected azo dyes from an aqueous solution by activated carbon derived from Monotheca buxifolia waste seeds. Soil Water Res. 2020, 15, 166-172. [CrossRef]

59. Muntean, S.G.; Rădulescu-Grad, M.E.; Sfarloaga, P. Dye adsorbed on copolymer, possible specific sorbent for metal ions removal. RSC Adv. 2014, 4, 27354-27362. [CrossRef]

60. Muntean, S.G.; Paska, O.; Coseri, S.; Simu, G.M.; Grad, M.E.; Ilia, G. Evaluation of a functionalized copolymer as adsorbent on direct dyes removal process: Kinetics and equilibrium studies. J. Appl. Polym. Sci. 2012, 127, 4409-4421. [CrossRef]

61. Muntean, S.G.; Szabadai, Z.; Halip, L. Investigation of aggregation behavior using computational methods and absorption spectra for trisazo direct dyes. Struct. Chem. 2015, 27, 1049-1059. [CrossRef]

62. Muntean, S.G.; Simu, G.M.; Kurunczi, L.; Szabadai, Z. Investigation of the aggregation of three disazo direct dyes by UV-Vis Spectroscopy and mathematical analysis. Rev. Chim. (Buchar.) 2009, 60, 152-156.

63. Lagergren, S. Zur theorie der sogenannten adsorption geloster stoffe. K.-Sven. Vetenskapsakademiens Handl. 1898, $24,1-39$.

64. Ho, Y.; McKay, G. Pseudo-second order model for sorption processes. Process. Biochem. 1999, 34, 451-465. [CrossRef]

65. Freundlich, H.M.F. Over the Adsorption in Solution. J. Phys. Chem. 1906, 57, 385-471.

66. Langmuir, I. The Adsorption of Gases on Plane Surfaces of Glass, Mica and Platinum. J. Am. Chem. Soc. 1918, 40, 1361-1403. [CrossRef]

67. Moeinpour, F.; Alimoradi, A.; Kazemi, M. Efficient removal of Eriochrome black-T from aqueous solution using NiFe2O4 magnetic nanoparticles. J. Environ. Health Sci. Eng. 2014, 12, 1-7. [CrossRef] 
68. Konicki, W.; Hełminiak, A.; Arabczyk, W.; Mijowska, E. Removal of anionic dyes using magnetic Fe@graphite core-shell nanocomposite as an adsorbent from aqueous solutions. J. Colloid Interface Sci. 2017, 497, 155-164. [CrossRef] [PubMed]

69. Gul, K.; Sohni, S.; Waqar, M.; Ahmad, F.; Norulaini, N.N.; Omar, A.K.M. Functionalization of magnetic chitosan with graphene oxide for removal of cationic and anionic dyes from aqueous solution. Carbohydr. Polym. 2016, 152, 520-531. [CrossRef]

70. Yao, Y.; Miao, S.; Liu, S.; Ma, L.P.; Sun, P.H.; Wang, S. Synthesis, characterization, and adsorption properties of magnetic Fe3O4@graphene nanocomposite. Chem. Eng. J. 2011, 184, 326-332. [CrossRef]

71. Nourmoradi, H.; Ghiasvand, A.; Noorimotlagh, Z. Removal of methylene blue and acid orange 7 from aqueous solutions by activated carbon coated with zinc oxide $(\mathrm{ZnO})$ nanoparticles: Equilibrium, kinetic, and thermodynamic study. DESALINATION Water Treat. 2014, 55, 252-262. [CrossRef]

72. Mahmoodi, N.M.; Abdi, J.; Bastani, D. Direct dyes removal using modified magnetic ferrite nanoparticle. J. Environ. Health Sci. Eng. 2014, 12, 96. [CrossRef] [PubMed]

73. Paşka, O.; Ianos, R.; Păcurariu, C.; Brădeanu, A. Magnetic nanopowder as effective adsorbent for the removal of Congo Red from aqueous solution. Water Sci. Technol. 2013, 69, 1234-1240. [CrossRef]

74. Gao, S.; Zhang, W.; An, Z.; Kong, S.; Chen, D. Adsorption of anionic dye onto magnetic Fe3O4/CeO2 nanocomposite: Equilibrium, kinetics, and thermodynamics. Adsorpt. Sci. Technol. 2019, 37, 185-204. [CrossRef]

75. Idan, I.J.; Abdullah, L.C.; Choong, T.S.; Jamil, S.N.A.B.M. Equilibrium, kinetics and thermodynamic adsorption studies of acid dyes on adsorbent developed from kenaf core fiber. Adsorpt. Sci. Technol. 2017, 36, 694-712. [CrossRef]

76. Kakavandi, B.; Jonidi, A.; Rezaei, R.; Nasseri, S.; Ameri, A.; Esrafily, A. Synthesis and properties of Fe3O4-activated carbon magnetic nanoparticles for removal of aniline from aqueous solution: Equilibrium, kinetic and thermodynamic studies. Iran. J. Environ. Health Sci. Eng. 2013, 10, 19. [CrossRef] [PubMed] 